\title{
Living (stained) benthic foraminifera from the Mozambique Channel (eastern Africa): Exploring ecology of deep-sea unicellular meiofauna
}

\author{
Fontanier Christophe ${ }^{1,{ }^{*}}$, Garnier Eline ${ }^{1,2}$, Brandily Christophe ${ }^{3}$, Dennielou Bernard ${ }^{1}$, Bichon S. ${ }^{2}$, \\ Gayet Nicolas ${ }^{3}$, Eugene Thibaut ${ }^{4}$, Rovere Mickael ${ }^{1}$, Grémare A. ${ }^{2}$, Deflandre B. ${ }^{2}$
}

${ }^{1}$ Ifremer, Laboratoire Environnements Sédimentaires, Centre de Brest, Technopôle de Brest-Iroise, BP 70, F-29280 Plouzané, France

2 Université de Bordeaux, CNRS, Environnements et Paléo-environnements Océaniques et

Continentaux, UMR 5805, F-33400 Talence, France

${ }^{3}$ Ifremer, Laboratoire Environnements Profonds, Centre de Brest, Technopôle de Brest-Iroise, BP 70,

F-29280 Plouzané, France

${ }^{4}$ Ifremer, Service Cartographie, Traitement de Données et Instrumentation, Centre de Brest, Technopôle de Brest-Iroise, BP 70, F-29280 Plouzané, France

* Corresponding author : Christophe Fontanier, email address : christophe.fontanier@ifremer.fr

\begin{abstract}
:
Live (Rose-Bengal stained) deep-sea foraminiferal faunas have been studied at four stations between 530-3200-m depth in the Mozambique Channel (eastern Africa) to understand how complex environmental conditions (e.g., organic matter, oxygenation) control their ecological structure (i.e., diversity, density, and microhabitats). Two upper-slope stations, located at 530- and 780-m depth off Madagascar, are bathed by well-oxygenated bottom waters. They are characterized by fine sediments enriched in highly degraded organic matter (low amino-acid bio-availability and reduced chlorophyllic freshness). Mineralization of organic compounds results in relatively moderate oxygen penetration depth (i.e., 15 and $30 \mathrm{~mm}$ ) in sediment. Interestingly, foraminiferal species richness (S) is exceptionally high at both sites. The highest densities are observed in the 780-m deep station, where peculiar sedimentary facies of organic matter are recorded $(\mathrm{OC}>2.0 \% \mathrm{DW})$. Redox conditions and sedimentary organic matter control the composition and the vertical distribution (i.e. microhabitat) of benthic faunas at both upper-slope sites. Bolivina alata, Bulimina marginata, Haplophragmoides bradyi and Nouria compressa are relevant bio-indicators of enhanced burial of organic matter prevailing at the $780-\mathrm{m}$ deep station (i.e., eutrophic conditions), whereas Uvigerina hispida and Uvigerina semiornata are dominant at the 530-m deep station (i.e., relatively mesotrophic conditions). Two other stations are located on wellventilated terraces from the deep-sea canyons of Tsiribihina and Zambezi (>3000-m depth). They are characterized by carbonate ooze, which is depleted in degraded organic matter and, where oxygen penetration depth is relatively deep (i.e., $>80 \mathrm{~mm}$ ). Because of food scarcity, $\mathrm{S}$ and densities are relatively low, and agglutinated and organic-walled taxa dominate foraminiferal faunas. Hospitella fulva, a foraminiferal species belonging to Allogromiida, occupies very deep infaunal microhabitat, what disrupts the classical scheme of microhabitat patterns in oligotrophic settings.
\end{abstract}




\section{Highlights}

- Living foraminifera from the Mozambique Channel are studied for the first time. A multidisciplinary approach allows gathering reliable environmental information. Sedimentary organic matter plays a major role on diversity, density and microhabitat.

Keywords : Mozambique Channel, Foraminifera, Diversity, Microhabitat, Organic matter

\section{Introduction}

In deep-sea ecosystems, both spatial and temporal dynamics of benthic foraminifera are controlled by various physico-chemical parameters (e.g., Gooday, 2003). In well-oxygenated ecosystems, the availability of sedimentary organic matter is the major ecological constraint in 
controlling foraminiferal diversity, densities, and microhabitats (e.g., Jorissen et al., 1998; Schmiedl et al., 2000; Fontanier et al., 2002, 2003, 2013, 2014a; Langezaal et al., 2006; Duchemin et al., 2007; Koho et al., 2007, 2008; Gooday et al., 2010; Duros et al., 2011, 2013). In fact, both sedimentary organic matter and dissolved oxygen penetration in the sediment define sedimentary habitable volume where different foraminiferal microhabitats overlap (e.g., Jorissen et al., 1995; Schmiedl et al., 2000; Fontanier et al., 2002, 2008a). This dependence of the benthic foraminiferal microhabitat on the availability of organic matter (i.e., food) and on oxygenation has been conceptualized by Jorissen et al. (1995). The so-called TROX-model explains that in oligotrophic and well-oxygenated ecosystems, shallow infaunal taxa will thrive close to the sediment-water interface. The scarcity of organic matter buried into the sediment (because of weak bioturbation and almost complete consumption of labile organic compounds in the first mms of the sediment) prevents occupation of the deeper sediment layers by infaunal species. Diversity and densities are therefore low. Under more eutrophic conditions, where the oxygenated layer is thinner, shallow infaunal taxa are limited to the first $\mathrm{mm}$ of the sediment. Densities are higher but diversity is depressed as an echo of discriminating metabolic adaptation required to survive in oxygen-depleted sediment. According to the TROX-model, faunal penetration (and diversity) will be maximal in mesotrophic settings, where oxygen penetration is relatively deep, and more or less bioavailable organic compounds are introduced at depth in the sediment by bioturbation. In such mesotrophic environments, deep-living intermediate and deep infaunal species may feed on degraded organic matter, graze on prokaryotic stocks, and rely on alternative metabolic pathway (e.g., nitrate respiration; Risgaard-Petersen et al., 2006; Høgslund et al., 2008; Glud et al., 2009; Piña-Ochoa et al. 2010; Koho et al., 2011; Bernhard et al. 2012a, b; Glock et al., 2012). The TROX-model has been validated in various marine areas (e.g., 
Schmiedl et al., 2000; Licari et al., 2003; Fontanier et al., 2002, 2008a, 2014a) although it appears that other environmental constraints such as hydro-sedimentary processes, temporary anoxia and interspecific competition for habitat and resources are important ecological variables in controlling foraminiferal dynamics (e.g., Gooday, 2003; Hess et al., 2005; Koho et al., 2007, 2008; Hess and Jorissen, 2009; Duros et al., 2011; Fontanier et al., 2013, 2014b). The overall structure of a living foraminiferal community is, therefore, a function of complex multifactorial controls, which makes benthic foraminifera reliable in biomonitoring and paleoenvironmental studies.

In this study, we present an ecological investigation of foraminiferal faunas at 4 deep-sea stations from the Mozambique Channel (Fig. 1; Table 1). This geographical area is of high scientific interest since it is unexplored in regards to deep-sea diversity particularly living benthic foraminifera. The Mozambique Channel is characterized by surface waters animated by large-scale gyres (so called "Mozambique Channel Eddies") superimposed on deep water masses with different origins (i.e., Antarctic, Atlantic, Indian oceans and the Red Sea) (e.g., Schouten et al., 2003; Ridderinkhof and De Ruitjer, 2003; Van Aken et al., 2004; Ridderinkhof et al., 2010; Ullgren et al., 2012; Ternon et al., 2014). Primary production is strongly dependent on hydrological fronts, divergence zones and local upwellings related to the vortical circulation and river runoff (e.g., Machu and Garçon, 2001; Tew-Kai and Marsac, 2009; Raj et al., 2010; Huggett, 2014; Malauene et al., 2014; Marsac et al., 2014; Roberts et al., 2014). One peculiar physiographic feature of the Mozambique Channel is the deep-sea Zambezi valley, which consists of a very steep canyon incising the southern basin. Its modern connection to the Zambezi River (the fourth longest river in Africa) is still debated, and its modern role in a source-to-sink transfer of organic and inorganic sediments from land to deep basin has never 
been determined. That said, Malagasy and Mozambican rivers flowing into the Mozambique Channel are numerous, and may play an important role in terms of sedimentary inputs. It is particularly true because both Madagascar and Mozambique are affected by a strong monsoon regime with an enhanced rainy period.

In our study, we have investigated the living (stained) foraminiferal communities in relation to environmental conditions and their distribution at and below the sediment-water interface. Foraminiferal densities, diversity, and microhabitats were studied at four selected stations in two different contrasted study areas from the Mozambique Channel. Two stations are located on the Malagasy north-western upper slope. They are close to major river mouths (Betsiboka and Mahavavy) (Fig. 1). Two other stations are located in the very deep basin, on terraces of Zambezi and Tsiribihina deep-sea canyons. Geochemical conditions (oxygen, sedimentary organic compounds) and sediment properties (grain-size distribution, lithofacies) were precisely described at these stations. We examined $\mathrm{OC}, \mathrm{C} / \mathrm{N}$ atomic ratio, $\delta^{13} \mathrm{C}_{\mathrm{OM}}$, amino acids, chlorophyllic pigments to get an overall description of both qualitative and quantitative changes in sedimentary organics. The aim of this ecological investigation was to assess the role played by sedimentary organic matter and the concentrations of dissolved oxygen (in pore and bottom waters) in controlling the structure of living foraminiferal faunas in view of unravelling their potential as proxies for detrital organic matter inputs at the seafloor and past redox (or bottom-water oxygen) conditions.

\section{Material and Methods}

\subsection{Study area}


The four stations were sampled during the PAMELA-MOZ1 cruise aboard the $\mathrm{R} / \mathrm{V}$ L'Atalante (Genavir-Ifremer) (Fig. 1; Table 1). This scientific cruise took place in October 2014, in the Mozambique Channel off Mozambique and Madagascar (eastern Africa). One major current dominates surface waters in this region: the Mozambique Current, which is mainly related to the South Equatorial Current originating from the central Indian Ocean (Schouten et al., 2003; Ridderinkhof et al., 2010; Ullgren et al., 2012; Ternon et al., 2014). The Mozambique Current is expressed in complex dipoles of anti-cyclonic and cyclonic eddies that flow southward through the western Mozambique Channel, and in turn generate partly the Agulhas Current. Those eddies produce hydrological fronts, divergence zones and upwellings, which affect surface and subsurface waters (Ridderinkhof and De Ruitjer, 2003). Below, the South Indian Central Water (SICW), which corresponds to the permanent thermocline (temperature between 8 and $13^{\circ} \mathrm{C}$, salinity between 34.8 and 35.2 ), occupies a depth range between 200 and $600 \mathrm{~m}$ depth (Ullgren et al., 2012). Intermediate waters are characterized by a complex mixture between oxygen-depleted and salty Red Sea Water (RSW; salinity > 34.7) from the north and lowsalinity, cold Antarctic Intermediate Water (AAIW; Salinity < 34.5) from the south (Roman and Lutjeharms, 2009; Ullgren et al., 2012). Below 1200 m depth, North Atlantic Deep Water (NADW) consists of a high-salinity (34.8) and well-oxygenated ( $>200 \mu \mathrm{mol} / \mathrm{L})$ water mass flowing into the Mozambique Channel from the south (Ridderinkhof and de Ruitjer, 2003; Van Aken et al., 2004). Antarctic Bottom Water (AABW) is located below $3500 \mathrm{~m}$ depth, and is characterized by temperature minima $\left(<1^{\circ} \mathrm{C}\right)$ and low salinity (34.7) (Van Aken et al., 2004). Regarding primary production, the Mozambique Channel is considered as a mesotrophic basin with values ranging between 100 and $150 \mathrm{gC} / \mathrm{m}^{2} / \mathrm{yr}$ (Antoine et al., 1996). Large phytoplankton 
blooms (mainly cyanobacteria and coccolithophorids) are recorded in austral summer (i.e., rainy period), with a linkage to coastal upwelling, precipitation along the Madagascar and Mozambique coasts, light penetration and local mesoscale circulation features in relation to eddies (Machu and Garçon, 2001; Tew-Kai and Marsac, 2009; Raj et al., 2010).

In our study, two stations are located on upper slope off north-western Madagascar, in the Comoro basin (Fig. 1). The so-called "Betsiboka slope" station (i.e., multi-corer deployments MTB-1 and MTB-2; 528-m depth) is located on the upper slope at $558 \mathrm{~m}$ depth, $50 \mathrm{~km}$ off the Betsiboka River mouth (Fig. 1; Table 1). It is bathed by SICW. The "Mahavavy slope" station (i.e., multi-corer deployments MTB-6 and MTB-7; $\sim 780-\mathrm{m}$ depth) is located $\sim 30 \mathrm{~km}$ southwestward from the previous station - but only $30 \mathrm{~km}$ far from the Mahavavy river mouth (Fig. 1). This station is bathed by an intermediate water mass consisting of a mixture between RSW and AAIW. It is noteworthy that the Betsiboka River is the main river of Madagascar in terms of length, watershed, as well as discharge (Berthois and Crosnier, 1965). It is characterized by a 20km-long estuary. Because of modern deforestation in its catchment basin, the Betsiboka estuary has evolved to a high sedimentation area and is characterised by one of the world's fastest coastal dynamics (Lebigre, 1990; Ralison et al., 2008). The Mahavavy is also an important Malagasy river that differs from the Betsiboka by its triangle-shape delta opened to the ocean. Two other stations investigated in this paper are located on well-ventilated sedimentary terraces inside the Tsiribihina and Zambezi deep-sea canyons (>3000-m depth), in the middle of the southern basin of the Mozambique Channel (Fig. 1; Table 1). The "Tsiribihina canyon" station (multi-corer deployments MTB-12 and MTB-13; 3082-m depth) and the "Zambezi canyon" station (multi-corer deployments MTB-10 and MTB-11; 3200-m depth) are bathed by NADW. 


\subsection{Sediment coring}

Sediment samples were collected with a Barnett-type multi-corer equipped with eight Plexiglas tubes (96-mm internal diameter; Barnett et al., 1984). The multi-corer allowed sampling of the upper decimetre of the sediment column, the overlying bottom waters, and a comparatively undisturbed sediment-water interface. It was deployed twice at each station (Table 1). A first core was selected for dissolved oxygen profiling and measurement of dissolved oxygen in bottom water (BWO; Table 1). A second core was sliced horizontally every $0.5 \mathrm{~cm}$ from the sediment-water interface to a 2-cm depth, every 1-cm between 4-10-cm depth, every 2$\mathrm{cm}$ between 10-20 $\mathrm{cm}$ depth and then every $5 \mathrm{~cm}$ downcore. Each sediment slice was immediately frozen $\left(-80^{\circ} \mathrm{C}\right)$ on board. Back at the EPOC laboratory (University of Bordeaux), sediment samples were analyzed for grain-size, porosity and sedimentary organic matter (OC,

$\mathrm{C} / \mathrm{N}$ atomic ratio, amino acids, chlorophyllic pigment, $\left.\delta^{13} \mathrm{C}_{\mathrm{OM}}\right) . \mathrm{A}$ third core was stored in PVC tube in a refrigerated container. Back at the Ifremer laboratory, it was split lengthwise in two half cores, and one half was photographed and radiographed by X-ray. Two duplicate cores per station were processed for foraminiferal investigation. It is noteworthy that duplicate cores recovered at each deep-basin station (Zambezi and the Tsiribihina canyons) were gathered from two different multi-corer deployments (Table 1).

\subsection{Geochemical Analysis}

\subsubsection{Bottom-Water Oxygen Concentration and Oxygen Profiles}


Oxygen concentrations in the bottom water at each station were determined by Winkler titration. A microsensor multimeter (Unisense S/A, Aarhus, Denmark) with a Clark type oxygen probe $\mathrm{Ox}-50$ and a motor controller were employed to record depth microprofiles from the sediment interface with a $500 \mu \mathrm{m}$ step. Data were collected by the SensorTrace PRO 3.1.0 software (Unisense).

\subsubsection{Organic-Matter Analyses}

All organic descriptors were analysed in triplicate. Total Carbon (TC) and nitrogen (TN) contents in sediments were measured on freeze-dried material by combustion using an automatic ThermoFinnigan EA1112 Series Flash Elemental analyser. Total Organic Carbon (OC) content was similarly measured on freeze-dried material after removal of carbonates with $2 \mathrm{M} \mathrm{HCl}$ from $50 \mathrm{mg}$ of powdered sample (Pastor et al., 2011). The reproducibility of these measurements was better than $5 \%$. C/N ratios (i.e. OC/TN) were expressed as atomic ratios. Sedimentary $\mathrm{CaCO}_{3}$ content was calculated by removing OC from TC contribution (multiplied by an 8.33 value). Total Hydrolysable Amino Acids (THAA) and Enzymatically Hydrolysable Amino Acids (EHAA) were assessed in freeze-dried sediment subsamples. Bulk sediment was first crushed and passed through a 200- $\mu$ m mesh. THAA and EHAA were assayed according to Mayer et al. (1995). Approximately $15 \mathrm{mg}$ DW (Dry Weight) of sediment were mixed with $500 \mu \mathrm{L}$ of $6 \mathrm{M}$ $\mathrm{HCl}\left(100^{\circ} \mathrm{C}\right)$ and kept under vacuum for $24 \mathrm{~h}$. Hydrolyzed subsamples $(100 \mu \mathrm{L})$ were neutralized with $100 \mu \mathrm{L}$ of $6 \mathrm{M} \mathrm{NaOH}$, and buffered with $2 \mathrm{~mL}$ of $\mathrm{H}_{3} \mathrm{BO}_{3}(0.4 \mathrm{M}, \mathrm{pH}=10)$. Fluorescent derivatives were obtained by adding $200 \mu \mathrm{L}$ of an orthophtaldialdehyde (OPA) solution (100 mg OPA $/ 1 \mathrm{~mL}$ methanol, $100 \mathrm{~mL}$ buffer $\mathrm{pH}=9.8$, and $0.05 \mathrm{~mL}$ mercaptoethanol) and $2 \mathrm{~mL}$ of 
phosphate buffer $(\mathrm{pH}=8)$ to $200 \mu \mathrm{L}$ of samples. Total hydrolysable amino acids were quantified $2 \frac{1}{2}$ min after OPA addition through fluorescence measurements $(340 \mathrm{~nm}$ excitation wavelength and $453 \mathrm{~nm}$ emission wavelength) taken with a Perkin Elmer LS55 fluorescence spectrometer. Enzymatically hydrolysable amino acids (EHAA) were extracted following a biomimetic approach (Mayer et al., 1995). Approximately $100 \mathrm{mg}$ of DW sediment were poisoned with a 1$\mathrm{mL}$ solution containing sodium arsenate $(0.1 \mathrm{M})$ and pentachlorophenol $(0.1 \mathrm{mM})$ within a sodium phosphate buffer $(\mathrm{pH}=8)$, and were incubated for $1 \mathrm{~h}$ at room temperature to prevent the bacterial utilization of amino acids released after the addition of $100 \mu \mathrm{L}$ of proteinase $\mathrm{K}$ solution $(1 \mathrm{mg} / \mathrm{mL})$. Sediment was then incubated for $6 \mathrm{~h}$ at $37^{\circ} \mathrm{C}$. After centrifugation, $75 \mu \mathrm{L}$ of pure trichloroacetic acid were added to $750 \mu \mathrm{L}$ of supernatant to precipitate macromolecules, which are considered to be unsuitable for absorption. After another centrifugation, $750 \mu \mathrm{L}$ of the supernatant were hydrolyzed and processed as described for THAA. A blank accounting for possible degradation of the enzyme was carried out. Enzymatically hydrolysable amino acids were then quantified using the procedure described above for THAA. The EHAA/THAA ratios (expressed in \%) were computed for each station (Rosenberg et al., 2003; Grémare et al., 2003; 2005; Pastor et al., 2011; Table 2). This ratio is indicative of the lability of amino acids. For chloropigments, $0.5-3.7 \mathrm{~g}$ FW (Fresh Weight) of frozen $\left(-80^{\circ} \mathrm{C}\right)$ sediment subsamples were extracted overnight at $4^{\circ} \mathrm{C}$ in darkness in $5 \mathrm{~mL}$ of $90 \%$ acetone (final concentration taking into account the water content of sediments). Fluorescence measurements were then performed using a Perkin Elmer ${ }^{\circledR}$ LS55 spectrofluorometer according to Neveux \& Lantoine (1993). This enabled for the assessment of chlorophyll $a(\mathrm{Chl}-a)$ and pheophytin $a$ (Phaeo- $a)$. The [Chl- $a /(\mathrm{Chl}-a+$ Phaeo-a)] ratios (expressed in \%) were computed for each station (Table 2) as indicative of the freshness of plant material. Stable carbon isotopes $\left(\delta^{13} \mathrm{C}_{\mathrm{OM}}\right)$ were measured from freeze-dried 
sediments treated with $\mathrm{HCl}(2 \mathrm{M})$ to remove carbonate, and then, subsequently rinsed with cold deionized water to remove chloride (Table 2). A few milligrams of powdered material were analyzed using an elemental analyzer (Carlo Erba NC2500) coupled to an Isotopic Ratio Mass Spectrometer (IR/MS, GVI Isoprime). The standard deviation for replicates of internal standards is less than $\pm 0.2 \%$ for isotopic ratios.

\subsection{Sediment properties}

Grain size was analyzed with a Malvern ${ }^{\circledR}$ Diffraction Particle Size Laser (type 2000) by using aliquots of the sediment samples dedicated to organic matter analysis. Before measuring, bulk (not decarbonated) sediments were immersed in water and moderately stirred with a plastic stick. The $10^{\text {th }}, 50^{\text {th, }}$ and $90^{\text {th }}$ percentiles $\left(\mathrm{D}_{10}, \mathrm{D}_{50}\right.$, and $\mathrm{D}_{90}$, respectively) were calculated for each sediment interval (Table 2). One half-core collected at each station was radiographed with a Geotek-MSCL-XCT. The aim of the X-ray radiography was to detect the presence of sedimentary structures in the top decimetres of the cores. In order to evaluate changes visually, a photograph of the same half-core was also taken.

\subsection{Benthic Foraminiferal Analysis}

Each core gathered for foraminiferal study was sliced horizontally every $0.5 \mathrm{~cm}$ from the sediment-water interface to $4-\mathrm{cm}$ depth, every 1 -cm between 4-10-cm depth. The corresponding samples were transferred on board ship into $500-\mathrm{cm}^{3}$ bottles, which were filled with $95 \%$ ethanol containing 2 g/L Rose Bengal stain, commonly used to identify live foraminifera (Walton, 1952; 
Murray \& Bowser, 2000). All samples were gently shaken for several minutes to obtain a homogeneous mixture. At the laboratory ( 3 months after the cruise), samples were sieved through both 63 and $125-\mu \mathrm{m}$ mesh screens, and the sieve residues were stored in $95 \%$ ethanol. The $63-125-\mu \mathrm{m}$ fraction is not discussed in this paper, because we chose to focus on the larger size fraction, which is widely used for biomonitoring and paleoceanography. Stained foraminifera belonging to the $>125-\mu \mathrm{m}$ fraction were sorted in wet samples and stored in Plummer slides. One problem with this technique is that Rose Bengal may stain the protoplasm of dead foraminifera that may be relatively well-preserved for long time periods under the generally anoxic conditions prevailing deep in sediments (Corliss \& Emerson, 1990; Bernhard, 2000). We therefore applied very strict staining criteria (i.e., all chambers except the last one stained bright pink), and compared doubtful individuals to perfectly stained ones of the same species found in the superficial sediment layers. Non-transparent agglutinated and porcelaneous taxa were broken to inspect the interior of the test. Most stained foraminifera were identified at species level (see Appendix A for census data). Because samples were preserved and sorted in ethanol, many soft-shelled foraminiferal species may have shrunk and become unrecognizable during picking. Thus, our counts probably underestimate the soft-shelled foraminiferal group. We obtained digital photographs of major species using a scanning electron microscope at Ifremer (FEI QUANTA 200 equipped with an Oxford Instrument Energy Dispersive Spectroscopy) (Fig. 2). For each core, we calculated different indices to assess diversity (Table 3). First, we calculated species richness (S). We also determined the $E\left(S_{50}\right)$ value in relation to the rarefaction curve (Table 3). This value represents the number of taxa identified after picking 50 specimens. As an information-statistic index, we calculated the Shannon index, H' (log base e), complemented by the Evenness index, E (Hayek \& Buzas, 1997), as described in Murray 
(2006). We showed the Berger-Parker index, which represents the highest relative contribution of a foraminiferal taxon in a fauna.

\section{Results}

\subsection{Bottom- and pore-water geochemistry}

Bottom-water oxygen (BWO) content ranges between $178 \mu \mathrm{mol} / \mathrm{L}$ at the "Mahavavy slope" station (multi-corer deployment MTB-6, $789 \mathrm{~m}$ depth) and $219 \mu \mathrm{mol} / \mathrm{L}$ at the "Zambezi canyon" station (multi-corer deployment MTB-10, 3205 m depth) (Table 1). Oxygen-penetration depth (OPD) at the "Mahavavy slope" station is $\sim 15 \mathrm{~mm}$ (Fig. 3). At the "Betsiboka slope" station (multi-corer deployment MTB-1, $529 \mathrm{~m}$ depth), where bottom-water oxygen is 190 $\mu \mathrm{mol} / \mathrm{L}$, OPD is $\sim 30 \mathrm{~mm}$ (Fig. 3). At the "Tsiribihina canyon" station (multi-corer deployment MTB-12, $3082 \mathrm{~m}$ depth), OPD exceeds $90 \mathrm{~mm}$. At the "Zambezi canyon" station (multi-corer deployment MTB-10, $3205 \mathrm{~m}$ depth), OPD ranges between 85 and $90 \mathrm{~mm}$.

\subsection{Sedimentary features and organic matter}

The «Betsiboka slope» site (multi-corer deployments MTB-1 and MTB-2, $529 \mathrm{~m}$ and $527 \mathrm{~m}$ depth respectively $)$ is characterized by silt-clay facies $\left(\mathrm{D}_{50}=10 \pm 1 \mu \mathrm{m}, \mathrm{D}_{90}=51 \pm 5 \mu \mathrm{m}\right.$; Table 2). Bioturbation is pervasive throughout the core and visible on the radiography in the form of density mottling and intricate burrows of several sizes (infracentimetric width) (Fig. 4). Sedimentary OC content presents a mean value of $1.2 \% \pm 0.2 \mathrm{DW}$ (Fig. 5a). It decreases in the first $\mathrm{cm} . \mathrm{CaCO}_{3}$ content is relatively constant with a mean value of $31.7 \% \pm 1.9 \mathrm{DW}$ (Table 2). The $\mathrm{C} / \mathrm{N}$ ratio shows only small changes within sediments, with a mean value of $9.4 \pm 0.2$. The 
$\delta^{13} \mathrm{C}_{\mathrm{OM}}$ in the first half $\mathrm{cm}$ is $-20.5 \%$ (Table 2 ). THAA decrease slightly with sediment depth with values ranging between 4.96 and $5.26 \mathrm{mg} / \mathrm{g}$ DW. EHAA values are an order of magnitude lower compared to THAA with values decreasing in the 10 uppermost $\mathrm{cm}$ of sediment (from 0.61 to $0.28 \mathrm{mg} / \mathrm{g}$ DW downcore). EHAA/THAA ratios decrease with sediment depth with values ranging between 7 and $12 \%$ (Fig. 5a). Chl- $a$ and Phaeo- $a$ contents change with sediment depth with values ranging between 0.07 and $0.49 \mu \mathrm{g} / \mathrm{g}$ FW for Chl- $a$, and between 0.96 à 6.12 $\mu \mathrm{g} / \mathrm{g}$ FW for Phaeo- $a$. The $[\mathrm{Chl}-a /(\mathrm{Chl}-a+$ Phaeo- $a)]$ ratios decrease from $13 \%$ to $9 \%$ between the sediment-water interface (SWI) and the 6-7 cm interval. Then, values are nearly constant down to $35 \mathrm{~cm}$ depth (Fig. 5a).

The «Mahavavy slope » site (multi-corer deployments MTB-6 and MTB-7, $789 \mathrm{~m}$ and $776 \mathrm{~m}$ depth respectively) is characterized by silt-clay facies $\left(\mathrm{D}_{50}=10 \pm 1 \mu \mathrm{m}, \mathrm{D}_{90}=41 \pm 4 \mu \mathrm{m}\right.$; Table 2; Fig. 5b). Bioturbation is pervasive throughout the core and visible on the radiography in the form of density mottling, though not as abundant as at "Betsiboka slope" station. On the radiography, two successive layers are characterized by sharp contacts between low density (light tone) and high density (dark tones) facies in the topmost $10 \mathrm{~cm}$ (Fig. 4). This interval also corresponds to colour branding from yellowish red, black and dark greenish grey. Sedimentary OC content presents a mean value of $1.6 \% \pm 0.4 \mathrm{DW}$ (Fig. 5b). It fluctuates downcore with maxima recorded in the first $\mathrm{cm}(1.7 \% \mathrm{DW})$, at $7 \mathrm{~cm}$ and $17 \mathrm{~cm}$ depth $(2.2 \% \mathrm{DW})$. Interestingly $\mathrm{OC}$ is well correlated to silt fraction $(10-63 \mu \mathrm{m})$ (i.e. $\mathrm{r}=0.74$, $\mathrm{p}$-value $<0.01$ ), and anticorrelated with clay fraction $(<10 \mu \mathrm{m})(\mathrm{r}=-0.71$, p value $<0.01) . \mathrm{CaCO}_{3}$ content is $11.0 \% \pm$ 10.7 DW with higher values ( $>20 \%)$ recorded in the lower part of the core. The $\mathrm{C} / \mathrm{N}$ ratio shows only small changes within sediments, with a mean value of $9.7 \pm 0.5$. The $\delta^{13} \mathrm{C}_{\mathrm{OM}}$ in the first half $\mathrm{cm}$ is $-21.9 \%$ (Table 2). THAA present the same vertical pattern as OC content with values 
ranging between 3.70 and $7.75 \mathrm{mg} / \mathrm{g} \mathrm{DW}(\mathrm{r}=0.94, \mathrm{p}$-value $<0.01)$. EHAA values are an order of magnitude lower compared to THAA with values comprised from 0.23 to $1.03 \mathrm{mg} / \mathrm{g} \mathrm{DW}$. They are also well correlated with OC content $(r=0.68$, $\mathrm{p}$-value $<0.01)$. EHAA/THAA ratios change with sediment depth with erratic values ranging between $6 \%$ and $19 \%$ (Fig. 5b). Chl- $a$ and Phaeo- $a$ contents change with sediment depth and show values ranging between 0.06 and $0.95 \mu \mathrm{g} / \mathrm{g} \mathrm{FW}$, and between 1.09 and $11.63 \mu \mathrm{g} / \mathrm{g} \mathrm{FW}$, respectively. The [Chl- $a /(\mathrm{Chl}-a+$ Phaeoa)] ratios decrease gradually downcore to $30 \mathrm{~cm}$ depth, from $12 \%$ to $5 \%$ (Fig. $5 \mathrm{~b}$ ).

The « Tsiribihina canyon » site (multi-corer deployments MTB-12 and MTB-13, $3082 \mathrm{~m}$ depth) is characterized by carbonate ooze with a strong contribution of large-sized planktonic foraminifera $\left(\mathrm{D}_{50}=10 \pm 2 \mu \mathrm{m}, \mathrm{D}_{90}=145 \pm 97 \mu \mathrm{m}\right.$; Table 2 and Fig. $\left.5 \mathrm{c}\right)$. Bioturbation is pervasive throughout the core and visible on the radiography dominantly in the form of horizontal centimetric burrows and density mottling (Fig. 4). $\mathrm{CaCO}_{3}$ content is $36.7 \% \pm 1.7 \mathrm{DW}$. At $30 \mathrm{~cm}$ depth, a horizontal millimetric indurated clayish layer enriched in iron $\left(\mathrm{Fe}_{2} \mathrm{O}_{3} ; \sim 30 \%\right.$ DW) is detected (Sandrine Chéron, personal communication). Organic descriptors exhibit relatively low values compared to previous stations. Sedimentary OC content presents a mean value of $0.5 \% \pm 0.1 \mathrm{DW}$ decreasing downcore from $0.6 \%$ to $0.3 \%$ (Fig. $5 \mathrm{c}$ ). The $\mathrm{C} / \mathrm{N}$ ratio shows only small changes within sediments, with a mean value of $9.2 \pm 0.4$. The $\delta^{13} \mathrm{COM}_{\mathrm{OM}}$ in the first half $\mathrm{cm}$ is $-20.0 \%$ (Table 2). THAA values decrease with sediment depth from $2.2 \mathrm{mg} / \mathrm{g}$ DW to 0.7 $\mathrm{mg} / \mathrm{g}$ DW. EHAA values are lower compared to THAA with values below $0.3 \mathrm{mg} / \mathrm{g}$ DW. Chl- $a$ and Phaeo- $a$ decrease abruptly with sediment depth, showing values below $0.09 \mu \mathrm{g} / \mathrm{g}$ FW for Chl- $a$, and below $0.75 \mu \mathrm{g} / \mathrm{g}$ FW for Phaeo- $a$.

The «Zambezi canyon» site (multi-corer deployments MTB-10 and MTB-11, $3205 \mathrm{~m}$ and $3206 \mathrm{~m}$ depth respectively) is characterized by carbonate ooze dominated by clay-silt 
particles $\left(\mathrm{D}_{50}=7 \pm 0 \mu \mathrm{m}, \mathrm{D}_{90}=45 \pm 6 \mu \mathrm{m}\right.$; Table 2; Fig. $\left.5 \mathrm{~d}\right) . \mathrm{CaCO}_{3}$ content is $41.1 \% \pm 6.2$ DW. Bioturbation is pervasive throughout the core and visible on the radiography dominantly in the form of centimetric to infracentimetric burrows and density mottling (Fig. 4). Sedimentary OC content presents a mean value of $0.6 \% \pm 0.1 \mathrm{DW}$ decreasing downcore from $0.8 \%$ to $0.5 \%$ (Fig. 5d). The C/N ratio shows only small changes within sediments, with a mean value of $9.1 \pm$ 0.3. The $\delta^{13} \mathrm{C}_{\mathrm{OM}}$ in the first half $\mathrm{cm}$ is $-20.0 \%$ (Table 2). THAA values decrease with sediment depth from $2.9 \mathrm{mg} / \mathrm{g}$ DW to $1.3 \mathrm{mg} / \mathrm{g}$ DW. EHAA values are lower compared to THAA with values decreasing also with sediment depth below $0.4 \mathrm{mg} / \mathrm{g}$ DW. Chl- $a$ and Phaeo- $a$ decrease abruptly with sediment depth, showing values below $0.1 \mu \mathrm{g} / \mathrm{g}$ FW for Chl- $a$, and below $0.8 \mu \mathrm{g} / \mathrm{g}$ FW for Phaeo- $a$.

\subsection{Live (stained) foraminiferal faunas}

\subsubsection{Densities and Diversity}

Foraminiferal densities vary between 268 individuals $/ 100 \mathrm{~cm}^{2}$ at the "Zambezi canyon" station (duplicate core MTB-11B, $3206 \mathrm{~m}$ depth) and 3,740 individuals $/ 100 \mathrm{~cm}^{2}$ at the "Mahavavy slope" station (duplicate core MTB-7B, $776 \mathrm{~m}$ depth; Table 3). There is a clear dichotomy between both deep-canyon stations, where densities are lower than 500 individuals $/ 100 \mathrm{~cm}^{2}$, and both upper-slope sites where density exceeds 1,000 individuals $/ 100 \mathrm{~cm}^{2}$ (Fig. 6a). S ranges between 36 at the "Tsiribihina canyon" station (duplicate core MTB-12A, $3082 \mathrm{~m}$ ) and 124 taxa at the "Betsiboka slope" station (duplicate core MTB-1A, $529 \mathrm{~m}$ ) (Fig. 6a). The $\mathrm{H}^{\prime}$ is low at the "Tsiribihina canyon" station (1.9 in duplicate core MTB-12A) and 
higher at the "Betsiboka slope" station (4.1 and 4.0 in both duplicate cores) (Table 3; Fig. 6b). Berger-Parker index is minimal at the upper-slope stations $(<0.21)$, and shows higher values in both deep canyons (Table 3).

\subsubsection{Foraminiferal Composition and Microhabitat}

At the "Betsiboka slope" station ( $\sim 530 \mathrm{~m})$, Bulimina marginata $(9-12 \%)$, Uvigerina hispida (6-13\%) and Uvigerina semiornata (6-7\%) are dominant calcareous species in both duplicate cores (Fig. 7a-b). Their abundances are maximal in the first $0.5 \mathrm{~cm}$ of the sediment column, as is usually the case for shallow-infaunal taxa. Rotorbinella lepida $(\sim 3 \%)$ presents also a shallow infaunal distribution. This species is frequently attached on biogenic fragments (e.g., pteropods). Melonis barleeanus ( $\sim \%$ in duplicate core MTB-1A) lives preferentially between 1 and $3 \mathrm{~cm}$. It is considered an intermediate-infaunal species (Fig. 7a). Globobulimina barbata (12\%) occupies the deep infaunal microhabitat (Appendix A). Among agglutinated taxa, which represent less than $35 \%$ of total live fauna, Lagenammina spp. and Reophax spp. are remarkable contributors.

At the "Mahavavy slope" station ( $\sim 780 \mathrm{~m})$, Bolivina alata (19-21\%), Nouria compressa (13-14\%), Bulimina marginata (11-14\%) and Haplophragmoides bradyi ( $8 \%)$ dominate the living fauna in both duplicate cores (Fig. 7c-d). Bulimina marginata and Haplophragmoides bradyi are shallow-infaunal species and their highest density are recorded in the first $\mathrm{cm}$ of the sediment column. Bolivina spathulata type $2(2-4 \%)$ is a shallow infaunal species too. Bolivina alata and Nouria compressa have an intermediate vertical distribution with density maxima recorded in the $0.5-2.0-\mathrm{cm}$ interval. Bulimina inflata $(2-8 \%)$, Melonis barleeanus $(<2 \%)$ and 
Pullenia bulloides $(<2 \%$ ) occupy intermediate microhabitat (Appendix A). Reophax spp. (Reophax horrida, Reophax spiculifera and Reophax hispidulus) regroups subsidiary agglutinated taxa $(<4 \%)$ presenting different microhabitats. It is noteworthy that agglutinated foraminifera account for $36-43 \%$ of the total living fauna, just after the calcareous ones representing more than $\sim 54 \%$.

At the "Tsiribihina canyon" station (3082 m), Hospitella fulva (16-58\%) and Reophax subfusiformis type 2 (10-12\%) dominate the living fauna (Fig. 7a-b). Reophax subfusiformis type 2, which belongs to agglutinated foraminiferal group, has a shallow infaunal vertical distribution. Hospitella fulva is a soft-walled taxon inhabiting inside test of dead planktonic foraminifera. It has also a shallow infaunal distribution in core MTB-13B, but a very deep infaunal vertical distribution in duplicate core MTB-12A. Reophax hispidulus (8\%), Reophax scorpiurus (6\%) and Reophax dentaliniformis (5\%) are remarkable species in core MTB-13B. Lagenammina arenulata and Nodellum membranaceum (types 1 and 2) represent subsidiary species (2-5\%) in both duplicate cores. Agglutinated and soft-walled foraminifera account for more than $75 \%$ of the living faunas.

At the "Zambezi canyon" station ( $\sim 3205 \mathrm{~m})$, Hospitella fulva (29-58\%) and Reophax subfusiformis type 2 (3-9\%) dominate the living fauna (Fig. 7c-d). Reophax subfusiformis type 2 has a shallow infaunal vertical distribution. Hospitella fulva has an intermediate-deep infaunal microhabitat in both duplicate cores. Nodellum membranaceum types 2 (7\%) and Reophax hispidulus (5\%), represent subsidiary species (7\%) in duplicate core MTB-11B. Lagenammina arenulata $(<5 \%)$ is a remarkable species in both duplicate cores. Agglutinated and soft-walled foraminifera account for more than $75 \%$ of the living faunas. 


\section{Discussion}

\subsection{Sedimentary features and particulate organic matter}

Surface sediments at both upper-slope stations off north-western Madagascar are clearly different from each other. The 530-m-deep site off the Betsiboka estuary ("Betsiboka slope station"; multi-corer deployments MTB-1 and -2) is characterised by homogeneous mud, and the 780-m-deep station off the Mahavavy delta ("Mahavavy slope station"; multi-corer deployments MTB-6 and -7) presents a succession of two distinct sediment layers overlying greenish grey facies (Fig. 4). Both layers are characterized by sub-horizontal sharp basal contacts revealed by X-ray. Regarding the most recent (i.e., uppermost) layer, sediments are nearly black in the lower part, and are overlain by a yellowish red facies made of (assumedly) laterite-derived and oxidised fine material (Fig. 4). Although it seems relevant to correlate the darkest interval with one of both organic-carbon content maxima (>1.7\% DW) recorded in the duplicate core MTB6, a point-by-point comparison between duplicate cores MTB-6 and MTB-7 is unreliable as far as both multi-corer deployments were not carried out exactly at the same location (Table 1). However, regarding grain-size features and sedimentary organic content in the MTB-6 core, the coarser (i.e. more silty) the sediments are the higher the OC content is. Vertical changes of OC content (values ranging between $1 \%$ and $2 \%$ DW) are peculiarly important. Therefore, our observations disrupt the classical paradigm according to which sedimentary organic compounds deposited on open margin focus preferentially in the finest sedimentary fraction. Conversely, our data suggest that hydro-sedimentary events have transferred to the "Mahavavy slope" station relatively coarse sediments enriched in organic matter $(>2 \% \mathrm{DW})$. Unfortunately, without 
radionuclide data (e.g., ${ }^{210} \mathrm{~Pb}_{\text {exc }}$ ), the periodicity of these episodes cannot be addressed. Sedimentary organics descriptors $\left(\mathrm{C} / \mathrm{N}\right.$ atomic ratio $=9.7 ; \delta^{13} \mathrm{C}_{\mathrm{OM}}=-21.9 \%$; amino acid bioavailability $=12 \%$ and chlorophyllic freshness $=7 \%$ ) suggest a strong contribution of highly degraded detritus with a putative marine origin (Savoye et al., 2003; Darnaude et al., 2004; Tesi et al., 2007). Regarding $\delta^{13} \mathrm{C}_{\mathrm{OM}}$ and $\mathrm{C} / \mathrm{N}$ ratio, sedimentary organic matter might include a mixture of mangrove- $\left(\mathrm{C} 3\right.$ type vegetation; $\left.\delta^{13} \mathrm{C}_{\mathrm{OM}}=-28.2 \%\right)$ and savannah-related detritus $(\mathrm{C} 4$ type vegetation, $\delta^{13} \mathrm{C}_{\mathrm{OM}}=-12.8 \%$ ) transferred from intertidal mangrove (Bouillon et al., 2007; Ralison et al., 2008). Ralison et al. (2008) have indeed suggested that sediments in the Betsiboka estuary are characterised by a mixture of C3- and C4-derived organic matter, the overall signatures $\left(\mathrm{C} / \mathrm{N}\right.$ ratio $=8.4-11.7 ; \delta^{13} \mathrm{C}_{\mathrm{OM}}=-19.8 \%$ of of wich match fairly well with our values. By extrapolating this pattern to the Mahavavy delta (in front of the "Mahavavy slope" station) and other adjacent coastal river, we can attempt to explain successive sedimentary layers observed in the duplicate core MTB-6 as results of turbidity flows generated by Malagasy rivers. Paroxysmal flood events (e.g., in relation to extreme rain episodes) might indeed create hyperpycnal flows, which would supply relatively coarse sediments and organic load from coastal zone to upper slope. Such extreme flood event would transfer a complex mixture of continental organic compounds (mainly $\mathrm{C} 3$ and $\mathrm{C} 4$ derived organic matter) and reworked/degraded marine phytodetritus. The overall variability of sedimentary $\mathrm{CaCO}_{3}$ content recorded at the "Mahavavy slope" station with lower values $(<15 \%$ DW) recorded in the uppermost $20 \mathrm{~cm}$ of core MTB-6 is a reliable evidence for a dominantly terrigenous source. To support our assumption, high-resolution bathymetric charts from the PAMELA project (unpublished data) suggest a plausible direct pathway between the Mahavavy deltaic area and the adjacent slope where both duplicate cores MTB-6 and -7 were gathered (i.e., "Mahavavy slope" 
station). Such a physiographic connection between the shallower "Betsiboka slope" station and both river mouths (Betsiboka and Mahavavy rivers) does not exist so far, what may explain (1) the absence of sedimentary stratification in duplicate cores MTB-1 and MTB-2, (2) a lower overall organic content compared to the deeper "Mahavavy slope" station and (3) a clear hemipelagic signature as underlined by relatively high and constant $\mathrm{CaCO}_{3}$ content $(>30 \% \mathrm{DW})$.

In the southern basin of the Mozambique Channel, surface sediments at both "Tsiribihina and Zambezi canyons" stations are characterized by carbonate ooze with a strong contribution of dead planktonic foraminifera. Grain-size analyses and radiographies have revealed neither fining-up deposits (e.g., a Bouma sequence) nor an erosional surface in the topmost decimetre of sediment. It is likely that the elevated position of both stations on terraces several hundred metres above canyon axes prevents the overflow of turbidity currents that may transit along the canyon. Accordingly, organic contents $(<0.6 \%$ DW) depict much more oligotrophic conditions compared to previous upper-slope stations off north-western Madagascar. However, regarding other organic descriptors $\left(\mathrm{C} / \mathrm{N}\right.$ atomic ratio $=\sim 9.2 ; \delta^{13} \mathrm{C}_{\mathrm{OM}}=-20.0 \%$; amino acid bio-availability $=6-10 \%$ and chlorophyllic freshness $=\sim 13 \%$ ), both canyon stations look fairly similar between each other and are obviously characterized by organic matter in an advanced state of decay (Grémare et al., 2003; Savoye et al., 2003; Darnaude et al., 2004; Tesi et al., 2007; HarmelinVivien et al., 2010). The origin of sedimentary organic matter is once again open to debate. An efficient transfer of a mixture of C3- and C4-derived organic matter from continental areas (e.g., via Malagasy river delta) onto canyon terraces is unlikely with regard to the pelagic composition of the sediment and considering the elevated and sheltered location of both stations and the distance to the continental sources. Therefore, it is suggested that highly degraded organic matter is mainly related to marine productivity exported to the seafloor. 


\subsection{Live foraminiferal faunas and environmental controls}

\subsubsection{Major trends}

In our study area, foraminiferal faunas exhibit very high diversity ( $>80$ taxa) at both upper-slope stations off north-western Madagascar, with more than 120 taxa recorded at the "Betsiboka slope" station (duplicate cores MTB-1A and MTB-1B) (Table 3). Densities are remarkably high at the "Mahavavy slope" site where the highest organic content (mean OC $=$ $1.6 \% \mathrm{DW}$ ) and the most labile organic compounds $(\mathrm{EHAA}>0.7 \mathrm{mg} / \mathrm{g} ; \mathrm{EHAA} / \mathrm{THAA}=12 \%)$ in the whole study area are recorded (Table 2). Density is even close to 4,000 individuals/100 $\mathrm{cm}^{2}$ in the duplicate core MTB-7B (Fig. 6). In comparison, both canyon stations are characterised by relatively low diversity and reduced densities. In well-oxygenated ecosystems, it is well known that foraminiferal diversity and densities are closely related to quantity and quality of sedimentary organic matter (e.g., Gooday, 2003; Murray, 2006). Therefore, the clear faunal dichotomy between canyon stations and upper-slope sites is considered a straightforward consequence of contrasted trophic levels characterizing both physiographic areas. Whereas meso-eutrophic conditions off north-western Madagascar (OC $>1.2 \%$ DW, EHAA $>0.40 \mathrm{mg} / \mathrm{g}$, $\mathrm{Chl}$ a $>0.25 \mu \mathrm{g} / \mathrm{g}$ ) sustain dense and highly diverse foraminiferal communities, oligotrophic settings in the southern deep basin (OC $<0.6 \%$ DW, EHAA $<0.20 \mathrm{mg} / \mathrm{g}$, Chl a $<0.02 \mu \mathrm{g} / \mathrm{g}$ ) support poor foraminiferal faunas. The overall dependency of foraminiferal faunas on labile organic matter is underlined by higher densities recorded just below the sediment-water interface where bio-available amino acids and relatively fresh phytodetritus are concentrated (Figs. 5 and 7). Such a relationship between sedimentary organic content and foraminiferal density/diversity 
has already been documented in many foraminiferal studies dealing with trophic transect along well-ventilated margin (e.g., Jorissen et al., 1998; Fontanier et al., 2002, 2008a; Licari et al., 2003; Eberwein and Mackensen, 2006; Koho et al., 2007; 2008; Duros et al., 2011; 2013). Regarding the potential role played by dissolved oxygen on living foraminiferal faunas, both bottom water oxygenation (> $180 \mu \mathrm{mol} / \mathrm{L})$ and oxygen penetration depth in sediment $(>15 \mathrm{~mm})$ promote a remarkable variety of microhabitats within sediments, what trigger ultimately an overall foraminiferal diversification in sedimentary environments off north-western Madagascar (Fig. 7).

\subsubsection{Compositional changes}

The change of trophic level between our different stations is illustrated by obvious differences in the composition of the foraminiferal faunas (Fig. 7). At the "Mahavavy slope" station, Bolivinids (e.g., Bolivina alata), Buliminids (e.g., Bulimina marginata), Nouria compressa and Haplophragmoides bradyi appear to benefit from deposits rich in more or less degraded organic compounds (Fig. 7). In many ecological studies, these taxa have been described as eutrophic species living in outer-shelf and/or upper-slope environments with high organic-matter fluxes (e.g., Licari et al., 2003; Duchemin et al., 2007; Langezaal et al., 2006; Eberwein and Mackensen, 2006; Fontanier et al., 2002; 2008b; 2013; Duros et al., 2011, 2013). Although Bolivinids are generally typical of organic-matter enriched sediments from oxygendepleted ecosystems (see review by Bernhard and Sen Gupta, 1999), they may also populate well-ventilated ecosystems (e.g., Hess et al., 2005, Langezaal et al., 2006; Hess and Jorissen, 2009). Bolivina alata, the most abundant taxon at the "Mahavavy slope" station, presents an 
intermediate infaunal microhabitat, what indicates its tolerance for in-sediment hypoxic conditions and a putative preference for degraded organic detritus (Fig. 7). Accordingly, B. alata was documented as a major intermediate infaunal species in the Saint-Tropez Canyon (NW Mediterranean Sea) at a station behaving as a depocenter for fine sediment and resuspended organic matter originating from shallower areas (Fontanier et al., 2008b). It was also a major contributor of intermediate rich and diverse faunas in the Cap Breton canyon area (NE Atlantic) (Hess and Jorissen, 2009). Hess and Jorissen (2009) proposed that B. alata was related to late stage of colonization in sediments after physical disturbance (e.g., turbidite), and it dominated living faunas with a preferential intermediate infaunal microhabitat in sedimentary environments not influenced by redepositional processes. Nouria compressa, the second most abundant taxon at the "Mahavavy slope" station, shows intermediate-to-deep infaunal habitats (Fig. 7). It is obviously capable of populating deeper hypoxic sediment layers, and relies likely on more or less altered organic matter available in subsurface layers. Like B. alata (and other subsidiary deep infaunal species such as Chilostomella czizeki), N. compressa may be capable of using nitrate to degrade organic compounds buried in the deeper sediments (Risgaard-Petersen et al., 2006; Piña-Ochoa et al. 2010). Alternatively, it may feed on prokaryotic biomass proliferating on organic remains or on break-up products. Nouria harrisii (a species close to our morphotype) has already been described in organic-matter enriched ecosystems from western African margin, where it occupied deep infaunal microhabitat (Licari et al., 2003; Fontanier et al., 2013). Bulimina marginata, one of the most important species at the "Mahavavy slope" station, presents a clear shallow infaunal microhabitat. In core MTB-7B, where the highest foraminiferal density is recorded, $B$. marginata is the most abundant taxon in the first half $\mathrm{cm}$, what may indicate its preference for relatively fresh and labile organic detritus. Bulimina marginata has already been 
recorded in organic-rich sediments from outer-shelf and upper-slope environments, where it behaved like an opportunistic, phytophagous taxon (e.g., Jorissen et al., 1998; Eberwein and Mackensen, 2006; Duchemin et al., 2007). It was also documented in many benthic environments characterised by sedimentary instability, where it behaved as a pioneer species able to colonise freshly deposited turbidite sediments and ephemerally active cold seeps (Hess et al., 2005; Hess and Jorissen, 2009; Fontanier et al., 2012, 2014a). Like B. marginata, Haplophragmoides bradyi occupies shallow infaunal microhabitat in oxygenated sediments. This vertical distribution suggests a preference for relatively fresh and labile organic matter.

At the "Betsiboka slope" station, Bolivinids and Buliminids are much less dominant compared to previous site (Fig. 7, Appendix A). Only Bulimina marginata maintains high relative abundance (9-12\%) and occupies shallow infaunal microhabitat. That said its absolute densities are at least half compared to density recorded at the 'Mahavavy slope' Station (Appendix A). Such a difference is likely related to the lower availability of fresh and labile organic matter at the "Betsiboka slope" station (Fig. 5). Uvigerinids (e.g. Uvigerina hispida and Uvigerina semiornata) are important contributors to living communities. They occupy the first $\mathrm{cm}$ of oxygenated sediment relying likely on relatively fresh organic compounds. $U$. hispida Schwager was described in western African margin as Uvigerina auberiana d'Orbigny in Licari et al. (2003), Licari and Mackensen (2005) and Fontanier et al. (2013). This species is commonly found in organic-rich environments, and may feed on altered organic matter (e.g. Licari et al., 2003; Licari and Mackensen, 2005; Fontanier et al., 2013; 2014a). Melonis barleeanus occupies an intermediate infaunal microhabitat at all duplicate cores from upper-margin stations. In other studies this taxon is commonly described from relatively organic-matter enriched sediments from upper slope and canyon settings (e.g., Fontanier et al., 2002, 2003, 2005, 2008a, 2008b; Licari et 
al., 2003; Licari and Mackensen, 2005; Eberwein and Mackensen, 2006; Koho et al., 2007, 2008; Duros et al., 2011, 2013). Panieri (2005) reported M. barleeanus from a hydrocarbon seep in the Rockall Trough and suggested that this species populates cold seeps because bacteria are particularly abundant there. Licari et al. (2003) and Licari and Mackensen (2005) described this infaunal species at $\sim 1300 \mathrm{~m}$ depth in the Gulf of Guinea and the northern Angola Basin. Its preference for degraded organic matter (and related bacterial pool) and its ability to thrive in hypoxic conditions within sediments may explain its occurrence and infaunal distribution in our study area (Caralp, 1989; Licari et al., 2003; Panieri, 2005; Fontanier et al., 2003, 2005). Finally, the occurrence of deep infaunal Globobulimina barbata underlines an optimal in-depth diversification of microhabitat in relation with the moderate OPD and the concomitant availability of food resources in hypoxic sediments. Globobulimina is indeed considered facultative anaerobe that prefers living in deep sediments where it can store a high concentration of nitrate in its large test for respiration (Risgaard-Petersen et al., 2006; Glud et al., 2009; Koho et al., 2011). Globobulimina can ingest fresh phytodetritus and also degraded organic detritus (Nomaki et al., 2005, 2006).

At both deep-canyon stations, agglutinated and organic-walled foraminifera represent $75 \%$ of the living faunas. The underrepresentation of calcareous taxa is likely related to the overall oligotrophication of deep-sea canyons compared to upper slope (e.g., Fontanier et al., 2008a; Phipps et al., 2012). Hospitella fulva that belongs to Allogromiida Order is the major organic-walled species identified at both sites. Firstly described in abyssal plain from the Northeast Atlantic (Rhumbler, 1911), this species has been recently documented in deep-sea ecosystems from the Mid-Atlantic Ridge (Gooday et al., 2013). Hospitella fulva is obliged to inhabit the empty shells of planktonic foraminifera (Fig. 2G-H), what limit its migration/motility 
ability. Therefore, its apparent microhabitat may be strongly dependent on biological and physical mixing controlling the vertical distribution/homogenization of biogenic particles (e.g. planktonic tests) in the topmost sediment layers. In our study area, H. fulva presents a very complex microhabitat characterized by density maxima recorded several $\mathrm{cm}$ down to dysoxic sediments. Inherent to the TROX-model is the notion that benthic foraminifera should be restricted to shallow microhabitat in oligotrophic settings (Jorissen et al., 1995). At our oligotrophic stations, foraminiferal microhabitats do not follow obviously this conceptual scheme but present a more complex distribution in relation to peculiar adaptation of deep-sea Allogromiida.

\section{Conclusions}

Live (Rose-Bengal stained) foraminiferal faunas show major changes in community structure (diversity, densities and microhabitats) between the four investigated sites in the Mozambique Channel (eastern Africa). Those changes are mainly related to qualitative and quantitative characteristics of sedimentary organic matter and oxygen penetration (i.e., OPD) in the sediments:

1. Both upper-slope stations, located off north-western Madagascar, are characterized by fine sediments enriched in degraded organic matter (low amino-acid bio-availability and reduced chlorophyllic freshness). Benthic mineralization of organic compounds results in relatively moderate oxygen penetration depth (OPD between 15 and 30 $\mathrm{mm}$ ). Foraminiferal species richness (S) is exceptionally high at both sites. The higher 
densities are observed in the 780-m deep station, where peculiar sedimentary events of organic matter focusing are recorded ( $\mathrm{OC}>2.0 \% \mathrm{DW})$.

2. Two other stations, which are located on well-ventilated terraces from the deep-sea canyons of Tsiribihina and Zambezi ( $>3000-\mathrm{m}$ depth), are characterized by carbonate ooze, unaffected by turbidites. These pelagic sediments are depleted in organic matter $(\mathrm{OC}<0.8 \% \mathrm{DW})$ whereas oxygen penetration depth is relatively deep $(\mathrm{OPD}>80$ $\mathrm{mm}$ ). Because of food scarcity, foraminiferal species richness (S) and densities are relatively low, and agglutinated and organic-walled taxa dominate foraminiferal faunas.

3. In terms of faunal composition and biomonitoring potential, Bolivina alata, Bulimina marginata, Haplophragmoides bradyi and Nouria compressa are obviously reliable bio-indicators of enhanced burial of low-nutritional-value organic matter prevailing in upper-margin eutrophic ecosystems. Uvigerinids (e.g. Uvigerina hispida), on the other hand, are adapted to live in relatively mesotrophic settings.

4. At both canyon stations, where fossilization potential for foraminiferal faunas is extremely poor, Hospitella fulva, a foraminifera belonging to Allogromiida, occupy very deep infaunal microhabitat. This peculiar and recurrent microhabitat patterns recorded in the four duplicate cores from both deep-sea canyons disrupts the classical TROX-model according to which foraminifera are restricted to shallow microhabitat in oligotrophic settings.

\section{Acknowledgments}


This study was done in the framework of the PAMELA project ("Passive Margin Exploration Laboratories") funded by TOTAL and Ifremer. We thank crew members of the R/V L'Atalante and all scientists who participate to the PAMELA-MOZ1 cruise. We sincerely acknowledge Karine Olu (Ifremer) and Stephan Jorry (Ifremer) for their very efficient work as chief scientist, in the organisation and the progress of the cruise. We have special thoughts for Lara Macheriotou ( $\mathrm{PhD}$, Ghent University) who sampled cores dedicated to foraminiferal investigation. We are grateful to Samuel Toucanne, Lucie Pastor and Alexis Khripounoff from Ifremer for their helpful comments on data sets. The Eline Garnier's fellowship was funded by the ECOBIOC team from the laboratory "Environnements et Paléo-environnements Océaniques et Continentaux" (UMR 5805), University of Bordeaux. Finally, we thank both reviewers - Dr. Fabrizio Frontalini and an anonymous one - for their helpful comments on the draft.

\section{Appendix A}

Census data for live (stained) benthic foraminifera in the $>125-\mu \mathrm{m}$ fraction for the height cores. N.B. Numbers are not standardized for sediment volume. Supplementary data associated with this article can be found in the online version at $\mathrm{xxxx}$.

\section{References}

Antoine, D., André, J.-M., and Morel, A., 1996, Oceanic primary production 2. Estimation at global scale from satellite (coastal zone color scanner) chlorophyll: Global Biogeochemical Cycles, v. 10, p. 57-69. 
Barnett, P.R.O., Watson, J., and Connely, D., 1984, A multiple corer for taking virtually undisturbed sample from shelf, bathyal and abyssal sediments: Oceanologica Acta, v. 7, p. 399-408.

Bernhard, J. M., 2000, Distinguishing live from dead foraminifera: methods review and proper applications: Micropaleontology, v. 46, p. 38-46.

Bernhard, J. M., and Sen Gupta, B. K., 1999, Foraminifera of oxygen-depleted environments: in Modern Foraminifera, Sen Gupta, B. K., (editor), Kluwer Academic Publishers, Dordrecht, The Netherlands, p. 201-216.

Bernhard, J. M., Casciotti, K. L., McIlvin, M. R., Beaudoin, D. J., Visscher, P. T., and Edgcomb, V. P., 2012a, Potential importance of physiologically diverse benthic foraminifera in sedimentary nitrate storage and respiration: J. Geophys. Res., v. 117, G03002, doi:10.1029/2012JG001949.

Bernhard, J. M., Edgcomb, V. P., Casciotti, K. L., McIlvin, M. R., and Beaudoin, D. J., 2012b, Denitrification likely catalyzed by endobionts in an allogromiid foraminifer: ISME J., v. 6, p. $951-960$.

Berthois, L., and Crosnier, A., 1965, La sédimentation dans l'estuaire de la Betsiboka (côte Ouest de Madagascar) et sur le plateau continental au large de l'estuaire: Sédimentologie. Comptes Rendus de l'Académie de Sciences Paris, v. 261, p. 3647-3649.

Bouillon, S., Dehairs, F., Schiettecatte, L.-S., Borges, A.V., 2007, Biogeochemistry of the Tana estuary and delta (northern Kenya): Limnology and Oceanography, v. 52, p. 46-59.

Corliss, B. H., and Emerson, S., 1990, Distribution of Rose Bengal stained deep-sea benthic foraminifera from the Nova Scotia continental margin and Gulf of Maine: Deep-Sea Research I, v. 37, p. 381-400. 
Darnaude, A. M., Salen-Picard, C., Polunin, N. V. C., and Harmelin-Vivien, M. L., 2004, Trophodynamic linkage between river runoff and coastal fishery yield elucidated by stable isotope data in the Gulf of Lions (NW Mediterranean): Oceanologica, v. 138, p. 325-332.

Duchemin, G., Fontanier, C., Jorissen, F. J., Barras, C., and Griveaud, C., 2007, Living smallsized $(63-150 \mu \mathrm{m})$ foraminifera from mid-shelf to mid-slope environments in the Bay of Biscay: Journal of Foraminiferal Research, v. 37, p. 12-32.

Duros, P., Fontanier, C., Metzger, E., Pusceddu, A., Cesbron, F., de Stigter, H. C., Bianchelli, S., Danovaro, R., and Jorissen, F. J., 2011, Live (stained) benthic foraminifera in the Whittard Canyon, Celtic margin (NE Atlantic): Deep-Sea Research I, v. 58, p. 128-146.

Duros, P., Fontanier, C., Metzger, E., Cesbron, F., Deflandre, B., Schmidt, S., Buscail, R., Zaragosi, S., Kerhervé, P., Rigaud, S., and Delgard, M.-L., 2013, Live (stained) benthic foraminifera from the Cap-Ferret Canyon (Bay of Biscay, NE Atlantic): A comparison between the canyon axis and the surrounding areas: Deep Sea Research Part I, v. 74, p. 98114.

Eberwein, A., Mackensen, A., 2006, Regional primary productivity differences off Morocco (NW-Africa) recorded by modern benthic foraminifera and their stable carbon isotopic composition: Deep-Sea Research part I, v. 53, p. 1379-1405.

Fontanier, C., Jorissen, F. J., Licari, L., Alexandre, A., Anschutz, P., and Carbonel, P., 2002, Live benthic foraminiferal faunas from the Bay of Biscay: faunal density, composition, and microhabitats: Deep-Sea Research I, v. 49, p. 751-785.

Fontanier, C., Jorissen, F. J., Chaillou, G., David, C., Anschutz, P., and Lafon, V., 2003, Seasonal and interannual variability of benthic foraminiferal faunas at $550 \mathrm{~m}$ depth in the Bay of Biscay: Deep-Sea Research I, v. 50, p. 457-494. 
Fontanier C., Jorissen, F. J., Chaillou, G., Anschutz, P., Grémare, A. And Griveaud, C. 2005, Live foraminiferal faunas from a $2800 \mathrm{~m}$ deep lower canyon station from the Bay of Biscay: Faunal response to focusing of refractory organic matter: Deep-Sea Research I, v. 52, 11891227.

Fontanier, C., Jorissen, F. J., Lansard, B., Mouret, A., Buscail, R., Schmidt, S., Kerhervé, P., Buron, F., Zaragosi, S., Hunault, G., Ernoult, E., Artero, C., Anschutz, P., and Rabouille, C., 2008a, Live (stained) foraminiferal faunas from open slope environments separating submarine canyons in the Gulf of Lions (NW Mediterranean): diversity, density and microhabitats: Deep-Sea Research I, v. 55, p. 1532-1553.

Fontanier, C., Jorissen, F., Geslin, E., Zaragosi, S., Duchemin, G., Laversin, M., and Gaultier, M., 2008b, Live and dead foraminiferal faunas from Saint-Tropez Canyon (Bay of Fréjus): Observations based on in situ and incubated cores: Journal of foraminiferal research, v. 28, p. $137-156$.

Fontanier, C., Metzger, E., Waelbroeck, C., Jouffreau, M., Lefloch, N., Jorissen, F.J., Etcheber, H., Bichon, S., Chabaud, G., Poirier, D., Grémare, A., and Deflandre, B., 2013, Live (stained) benthic foraminifera off Walvis Bay (Namibia): A deep-sea ecosystem under the influence of benthic nepheloid layers: Journal of Foraminiferal Research, v. 43, p. 50-66.

Fontanier, C., Koho, K. A., Goñi-Urriza, M.S., Deflandre, B., Galaup, S., Ivanovsky, A.,Gayet, N, Dennielou, B, Grémare, A., Bichon, S., Gassie, C., Anschutz, P., Duran, R., and Reichart, G. J., 2014a, Benthic Foraminifera from the deep-water Niger delta (Gulf of Guinea): Assessing present-day and past activity of hydrate pockmarks: Deep-Sea Research part-I, v. 94, p. $87-106$. 
Fontanier, C., Duros, P., Toyofuku, T., Oguri, K., Koho, K.A., Buscail, R., Grémare, A., Radakovitch, O., Deflandre, B., De Nooijer, L.J., Bichon, S., Goubet, S., Ivanovsky, I., Chabaud, G., Menniti, C., Reichar,t G.J., and Kitazato, H., 2014b, Living (stained) deep-sea foraminifera off Hachinohe (NE Japan, Western Pacific): Environmental interplay in oxygen-depleted ecosystems: Journal of Foraminiferal Research, v. 44, p. 281-299.

Glud, R. N., Thamdrup, B., Stahl, H., Wenzhoefer, F., Glud, A., Nomaki, H., Oguri, K., Revsbech, N. P., and Kitazato, H., 2009, Nitrogen cycling in a deep ocean margin sediment (Sagami bay, Japan): Limnology and Oceanography, v. 54, p. 723-734.

Glock, N., Schönfeld, J., Eisenhauer, A., Hensen, C., Mallon, J., and Sommer, S., 2012, The role of benthic foraminifera in the benthic nitrogen cycle of the Peruvian oxygen minimum zone: Biogeosciences Discussions, v. 9, p. 17775-17817.

Gooday, A. J., 2003, Benthic Foraminifera (Protista) as tools in deep-water palaeoceanography: environmental influences on faunal characteristics: Advances in Marine Biology, v. 46, p. $1-90$.

Gooday, A. J., Malzone, M. G., Bett, B. J., and Lamont, P. A., 2010, Decadal-scale changes in shallow-infaunal foraminiferal assemblages at the Porcupine Abyssal Plain, NE Atlantic: Deep-sea Research II, v. 57, p. 1362-1382.

Gooday, A. J., Rothe N., and Pearce R. B., 2013, New and poorly known benthic foraminifera (Protista, Rhizaria) inhabiting the shells of planktonic foraminifera on the bathyal MidAtlantic Ridge: Marine Biology Research, v. 9, p. 447-461.

Grémare, A., Medernach, L., De Bovée, F., Amouroux , J.-M., Charles, F., Dinet, A., Vétion, G., Albert, P., and Colomines, J.-C., 2003, Relationship between sedimentary organic matter and benthic fauna within the Gulf of Lion: synthesis on the identification of new 
biochemical descriptors of sedimentary organic nutritional value: Oceanologica Acta, v. 26, p. 391-406.

Grémare, A., Guttiérrez, D., Anschutz, P., Amouroux, J.-M., Deflandre, B., and Vétion, G., 2005, Spatio-temporal changes in totally and enzymatically hydrolysable amino acids of superficial sediments from three contrasted areas: Progress in Oceanography, v. 65, p. 89111.

Hammer, Ø, Harper, D. A. T., and Ryan, P. D., 2001, PAST: Paleontological statistics software package for education and data analysis: Palaeontologica Electronica, v. 4, 9 pp.

Hayek, L. E. C., and Buzas, M. A., 1997, Surveying Natural Populations: Columbia University Press, New York, 563 pp.

Hess, S., Jorissen, F. J., Venet, V., and Abu-Zied, R., 2005, Benthic foraminiferal recovery after recent turbidite deposition in Cap Breton canyon, Bay of Biscay: Journal of Foraminiferal Research, v. 35 (2), p. 114-129.

Hess, S., and Jorissen, F. J., 2009, Distribution patterns of living benthic foraminifera from Cap Breton Canyon, Bay of Biscay: faunal response to sediment instability: Deep-Sea Research I, v. 56, p. $1555-1578$.

Høgslund, S., Revsbech, N. P., Cedhagen, T., Nelsen, L. P., and Gallardo, V. A., 2008, Denitrification, nitrate turn over, and aerobic respiration by benthic foraminiferans in the oxygen minimum zone off Chile: Journal of Experimental Marine Biology and Ecology, v. 359, p. 85-91.

Huggett, J.A., 2014, Mesoscale distribution and community composition of zooplankton in the Mozambique Channel: Deep-Sea Research part II, v. 100, p. 119-135. 
Jorissen, F.J., de Stigter, H.C., and Widmark, J.G.V., 1995, A conceptual model explaining benthic foraminiferal microhabitats. Marine Micropaleontology 22, 3-1715.

Jorissen, F. J., Wittling, I., Peypouquet, J.-P., Rabouille, C., and Relexans, J.-C., 1998, Live benthic foraminiferal faunas off Cap Blanc, NW Africa: community structure and microhabitats: Deep-Sea Research I, v. 45, p. 2157-2188.

Koho, K. A., Kouwenhoven, T. J., de Stigter, H. C., and van der Zwaan, G. J., 2007, Benthic foraminifera in the Nazaré Canyon, Portuguese continental margin: sedimentary environments and disturbance: Marine Micropaleontology, v. 66, p. $27-51$.

Koho, K. A., García, R., de Stigter, H. C., Epping, E., Koning, E., Kouwenhoven, T. J., and van der Zwaan, G. J., 2008, Sedimentary labile organic carbon and pore water redox control on species distribution of benthic foraminifera: a case study from Lisbon-Setúbal Canyon (southern Portugal): Progress in Oceanography, v. 79, p. 55-82.

Koho, K. A., Piña-Ochoa, E., Geslin, E., and Risgaard-Petersen, N., 2011, Vertical migration, nitrate uptake and denitrification: Survival mechanisms of foraminifers (Globobulimina turgida) under low oxygen conditions: FEMS Microbiology Ecology, v. 75, p. 273-283.

Langezaal, A. M., Jorissen, F. J., Braun, B., Chaillou, G., Fontanier, C., Anschutz, P., and van der Zwaan, G. J., 2006, The influence of seasonal processes on geochemical profiles and foraminiferal assemblages on the outer shelf of the Bay of Biscay: Continental Shelf Research, v. 26, p. 1730-1755.

Lebigre, J.M., 1990, Les marais maritimes de Gabon et de Madagascar. Contribution à l'étude d'un milieu tropical : PhD thesis, Institut de Géographie, Université de Bordeaux III, 988 pp. 
Licari, L.N., Schumacher, S., Wenzhöfer, F., Zabel, M., and Mackensen, A., 2003, Communities and microhabitats of living benthic foraminifera from the tropical east Atlantic: impact of different productivity regimes: Journal of Foraminiferal Research, v. 33, p. 10-31.

Licari, L.N., Mackensen, A., 2005, Benthic foraminifera off West Africa (11N to321S): do live assemblages from the topmost sediment reliably record environmental variability?: Marine Micropaleontology, v. 55, p. 205-233.

Machu, E., and Garçon, V., 2001, Phytoplankton seasonal distribution from SeaWIFS data in the Agulhas Current system: Journal of Marine Research, v. 59, p. 795-812.

Malauene, B.S., Shillington, F.A., Roberts, M.J., and Moloney, C.L., 2014, Cool, elevated chlorophyll-a waters off northern Mozambique: Deep-Sea Research part II, v. 100, p. 6878.

Marsac, F., Barlow, R., Ternon, J.-F., Ménard, F., and Roberts, M., 2014, Ecosystem functioning in the Mozambique Channel: Synthesis and future research. Deep-Sea Research part II, v. 100, p. 212-220.

Mayer, L. M., Schick, L. L., Sawyer, T., Plante, C., Jumars, P. A., and Self, R. L., 1995, Bioavailable amino acids in sediments: a biomimetic, kinetics-based approach: Limnology and Oceanography, v. 40, p. 511-520.

Murray, J. W., 2006, Ecology and Applications of Benthic Foraminifera: Cambridge University Press, Cambridge, 426 pp.

Murray, J. W., and Bowser, S. S., 2000, Mortality, protoplasm decay rate, and reliability of staining techniques to recognize "living" foraminifera: a review: Journal of Foraminiferal Research, v. 30, p. 66-70. 
Neveux, J., and Lantoine, F., 1993, Spectrofluorometric assay of chlorophylls and phaeopigments using the least squares approximation technique: Deep-Sea Research I, v. 40 (9), p. 1747-1765.

Nomaki, H., Heinz, P., Hemleben, C., and Kitazato, H., 2005, Behavior and response of deep-sea benthic foraminifera to freshly supplied organic matter: a laboratory feeding experiment in microcosm environments: Journal of Foraminiferal Research, 35, p. 103-113.

Nomaki, H., Heinz, P., Nakatsuka, T., Shimanaga, M., Ohkouchi, N., Ogawa, N. O., Kogure, K., Ikemoto, E., and Kitazato, H., 2006, Different ingestion patterns of ${ }^{13}$ C-labeled bacteria and algae by deep-sea benthic foraminifera: Marine Ecology Progress Series, v. 310, p. 95-108.

Panieri, G., 2005, Benthic foraminifera associated with a hydrocarbon seep in the Rockall Trough (NE Atlantic): Geobios, v. 38(2), p. 247-255.

Pastor, L., Deflandre, B., Viollier, E., Cathalot, C., Metzger, E., Rabouille, C., Escoubeyrou, K., Lloret, E., Pruski, A. M., Vétion, G., Desmalades, M., Buscail, R., and Grémare, A., 2011, Influence of the organic matter composition on benthic oxygen demand in the Rhône River prodelta (NW Mediterranean Sea): Continental Shelf Research v. 31, p. 1008-1019.

Phipps, M., Jorissen, F., Pusceddu, A., Bianchelli, S., and De Stigter, H., 2012, Live benthic foraminiferal faunas along a bathymetrical transect $(282-4987 \mathrm{~m})$ on the Portuguese margin (NE Atlantic): Journal of Foraminiferal Research, v. 42, p. 66-81.

Piña-Ochoa, E., Koho, K. A., Geslin, E., and Risgaard-Petersen, N., 2010, Survival and life strategy of the foraminiferan Globobulimina turgida through nitrate storage and denitrification: Marine Ecology Progress Series, v. 417, p. 39-49. 
Raj, R. P., Peter, B. N., and Pushpadas, D., 2010, Oceanic and atmospheric influences on the variability of phytoplankton bloom in the Southwestern Indian Ocean: Journal of Marine Systems, v. 82, p. 217-229.

Ralison, H., R., Borger, A. V., Dehairs, F., Middelburg, J.J., and S. Bouillon, 2008, Carbon biogeochemistry of the Betsiboka estuary (north-western Madagascar): Organic Geochemistry, doi:10.1016/j.orggeocem.2008.01.010.

Rhumbler, L. 1911, Die Foraminiferen (Thalamophoren) der Plankton Expedition. Zugleich Entwurf eines natuerlichen Systems der Foraminiferen auf Grund selektonischer und mechanisch-physiologischer Faktoren. Erste Teil, Die allgemeinen Organizationsverhaltnisse der Foraminiferen. Ergebnisse der Plankton-Expedition der Humboldt Stiftung. Kiel und Leipzig. Verlag von Lipsius \& Tischer (1909), p. 1-331.

Ridderinkhof, H., and de Ruijter, W.P.M., 2003, Moored current observations in the Mozambique Channel: Deep-Sea Research part II, v. 50, p. 1953-1955.

Ridderinkhof, H., van der Werf, P.M., Ullgren, J.E., van Aken, H.M., van Leeuwen, P.J., and de Ruijter, W.P.M., 2010, Seasonal and interannual variability in the Mozambique Channel from moored current observations: Journal of Geophysical Research, v. 115, http://dx.doi.org/10.1029/2009JC005619.

Risgaard-Petersen, N., Langezaal, A., Ingvardsen, S., Schmid, M. C., Jetten, M. S. M, Op den Camp, H. J. M., Derksen, J. W. M., Piña-Ochoa, E., Eriksson, S. P., Nielsen, S. P., Revsbech, N. P., Cedhagen, T., and van der Zwaan, G. J., 2006, Evidence for complete denitrification in a benthic foraminifer: Nature, v. 443, p. 93-96.

Roberts, M.J., Ternon, J.-F., and Morris, T., 2014, Interaction of dipole eddies with the western continental slope of the Mozambique Channel: Deep-Sea Research part II, v. 100, p. 54-67. 
Roman, R.E., and Lutjeharms, J.R.E., 2009, Red Sea Intermediate Water in the source regions of the Agulhas Current: Deep-Sea Research part-I, v. 56, p. 939-962.

Rosenberg, W., Nierop, K. G. J., Knicker, H., de Jager, P. A., Kreutzer, K., and Weiss, T., 2003, Liming effects on the chemical composition of the organic surface layer of a mature Norway spruce stand (Picea abies [L.] Karst.): Soil Biology and Biochemistry, v. 35, p. 155-165.

Savoye, N., Aminot, A., Tréguer, P., Fontugne, M., Naulet, M., Kérouel, R., 2003, Dynamics of particulate organic matter $\mathrm{d} 15 \mathrm{~N}$ and $\mathrm{d} 13 \mathrm{C}$ during spring phytoplankton blooms in a macrotidal ecosystem (Bay of Seine, France): Marine Ecology Progress Seriers, v. 255, p. $27-41$.

Schmiedl, G., De Bovée, F., Buscail, R., Charrière, B., Hemleben, C, Medernach, L., and Picon, P., 2000. Trophic control of benthic foraminiferal abundance and microhabitat in the bathyal Gulf of Lions, Western Mediterranean Sea: Marine Micropaleontology, v. 40, p. 167-188.

Schouten, M.W., de Ruijter, W.P.M., van Leeuwen, P.J., and Ridderinkhof, H., 2003, Eddies and variability in the Mozambique Channel: Deep-Sea Research part II, v. 50, p. 1987-2003.

Ternon, J.F., Roberts, M.J., Torris, T., Hancke, L., and Backeberg, B., 2014, In situ measured current structures of the eddy field in the Mozambique Channel: Deep-Sea Research part II, v. 100 , p. $10-26$.

Tesi, T., Miserocchi, S., Goni, M.A., Langone, L., 2007, Source, transport and fate of terrestrial organic carbon on the western Mediterranean Sea, Gulf of Lions, France: Marine Chemistry v. 105 , p. $101-117$.

Tew-Kai, E., and Marsac, F., 2009, Patterns of variability of sea surface chlorophyll in the Mozambique Channel: a quantitative approach: Journal of Marine Systems, v. 77, p. 77-88. 
Ullgren, J.E., van Aken H.M., Ridderinkhof, H., and de Ruijter, W.P.M., 2012, The hydrography of Mozambique Channel from six years of continuous temperature, salinity, and velocity observations: Deep-Sea Research part I, v. 69, p. 36-50.

Van Aken, H. M., Ridderinkhof, H., and de Ruijter, W.P.M., 2004, North Atlantic deep water in the south-western Indian Ocean: Deep-Sea Research part I, v. 51, p. 755-776.

Walton, W. R., 1952, Techniques for recognition of living Foraminifera: Contributions from the Cushman Foundation for Foraminiferal Research, v 3, p. 56-60.

\section{Figure Captions}

Figure 1. Bathymetry and location of the four investigated stations in the Mozambique Channel (eastern Africa). At each station, both multi-corer deployments are indicated. Stations, multicorer depths and geographic positions are listed in Table 1.

Figure 2. SEM photographs of dominant foraminiferal species observed at the four stations. Scale bars represent $200 \mu \mathrm{m}$. A. Bolivina alata (MTB-7A, 0-0.5 cm interval). B. Bolivina spathulata type 2 (MTB-7B, 0-0.5 cm interval). C. Bulimina inflata (MTB-7B, 0-0.5 cm interval). D. Bulimina marginata (MTB-7B, 0-0.5 cm interval). E-F. Haplophragmoides bradyi 
(MTB-7B, 0-0.5 cm interval). G-H. Hospitella fulva (MTB-10A, 0.5-1 cm interval). I. Lagenammina arenulata (MTB-10A, 0-0.5 cm interval). J. Melonis barleeanus (MTB-1A, 2-3 $\mathrm{cm}$ interval). K. Nodellum membranaceum type 1 (MTB-12A, 4-5 cm interval). L. Nodellum membranaceum type 2 (MTB-11B, 6-7 cm interval). M. Nouria compressa (MTB-7A, 1-1.5 cm interval). N. Reophax dentaliniformis (MTB-7B, 0-0.5 cm interval). O. Reophax hispidulus (MTB-10A, 0.5-1 cm). P. Reophax horrida (MTB-7A, 1-1.5 cm interval). Q. Reophax spiculifera (MTB-6B, 0-0.5 cm interval). R. Reophax subfusiformis type 1 (MTB-10A, 0-0.5 cm interval). S. Reophax subfusiformis type 2 (MTB-10A, 0-0.5 $\mathrm{cm}$ interval). T. Uvigerina hispida (MTB-1A, 0-0.5 cm interval). U. Uvigerina semiornata (MTB-1 A, 0-0.5 cm interval). NB: The differentiation between Bolivina spathulata type 1 and type 2 is based on the proloculus size. Bolivina spathulata type 1 presents a large spherical proloculus, which suggests a megalospheric morphotype. Bolivina spathulata type 2 has a very tiny proloculus (potentiallly, microspheric morphotype).

Figure 3. Depth profiles of dissolved oxygen $\left(\mathrm{O}_{2}\right)$ concentrations in sediments at the four stations. SWI refers to sediment-water interface.

Figure 4. Sedimentological features (photograph and X-Ray radiograph) of the four investigated cores.

Figure 5. Depth profiles of grain-size $\left(\mathrm{D}_{10}, \mathrm{D}_{50}\right.$, and $\left.\mathrm{D}_{90}\right)$ and organic descriptors: organic content (OC in \% DW), $\mathrm{C} / \mathrm{N}$ atomic ratio, total and enzymatically hydrolysable amino acids (EHAA and THAA), and their bio-availability (EHAA/THAA ratio), chlorophyllic pigment content (i.e. Chl- 
$a$ and Phaeo- $a)$, their lability index Chl- $a /(\mathrm{Chl}-a+\mathrm{Phaeo}-a)$ and calcium carbonate content $\left(\mathrm{CaCO}_{3}\right.$ in $\%$ DW) content.

Figure 6a-b. Foraminiferal densities (No individuals/100 $\mathrm{cm}^{2}$ ), species richness (S), Shannon index $\left(\mathrm{H}^{\prime}\right)$ and Berger-Parker index for the 8 cores collected at our four stations.

Figure 7. Down core distribution of live benthic foraminifers in the 8 cores gathered at the 4 sites ( 2 duplicate cores per station). The number of individuals belonging to the $>125-\mu \mathrm{m}$ fraction found in each level is standardized for a $50-\mathrm{cm}^{3}$ sediment volume. Only taxa with relative abundances $>2.5 \%$ are pictured. Note the change of density scale between the stations. Pie charts represent the composition of live benthic foraminiferal faunas (composition in $\%$ total fauna). As above, only taxa with relative abundances $>2.5 \%$ are pictured.

\section{Table Captions}

Table 1. Location and physiographical description of the 4 stations sampled during the PAMELA-MOZ1 cruise (October 2014). Two multi-corer deployments were operated at each site. Coordinates and depth of all deployments are described. Physico-chemical parameters 
including BWT (bottom-water temperature) and BWS (bottom-water salinity) were extrapolated from CTD casts achieved during the ACSEX (single asterisk) and the M75-1B (double asterisks) cruises (data available at http://www.nioz.nl/codis). BWO (bottom-water oxygen) was measured in water overlying the sediment-water interface (SWI) of cores gathered at the occasion of the PAMELA-MOZ1 cruise. Details showing how cores were shared between scientific tasks (e.g., foraminiferal study, organic matter description) are explicated in the Materials-and-Methods section.

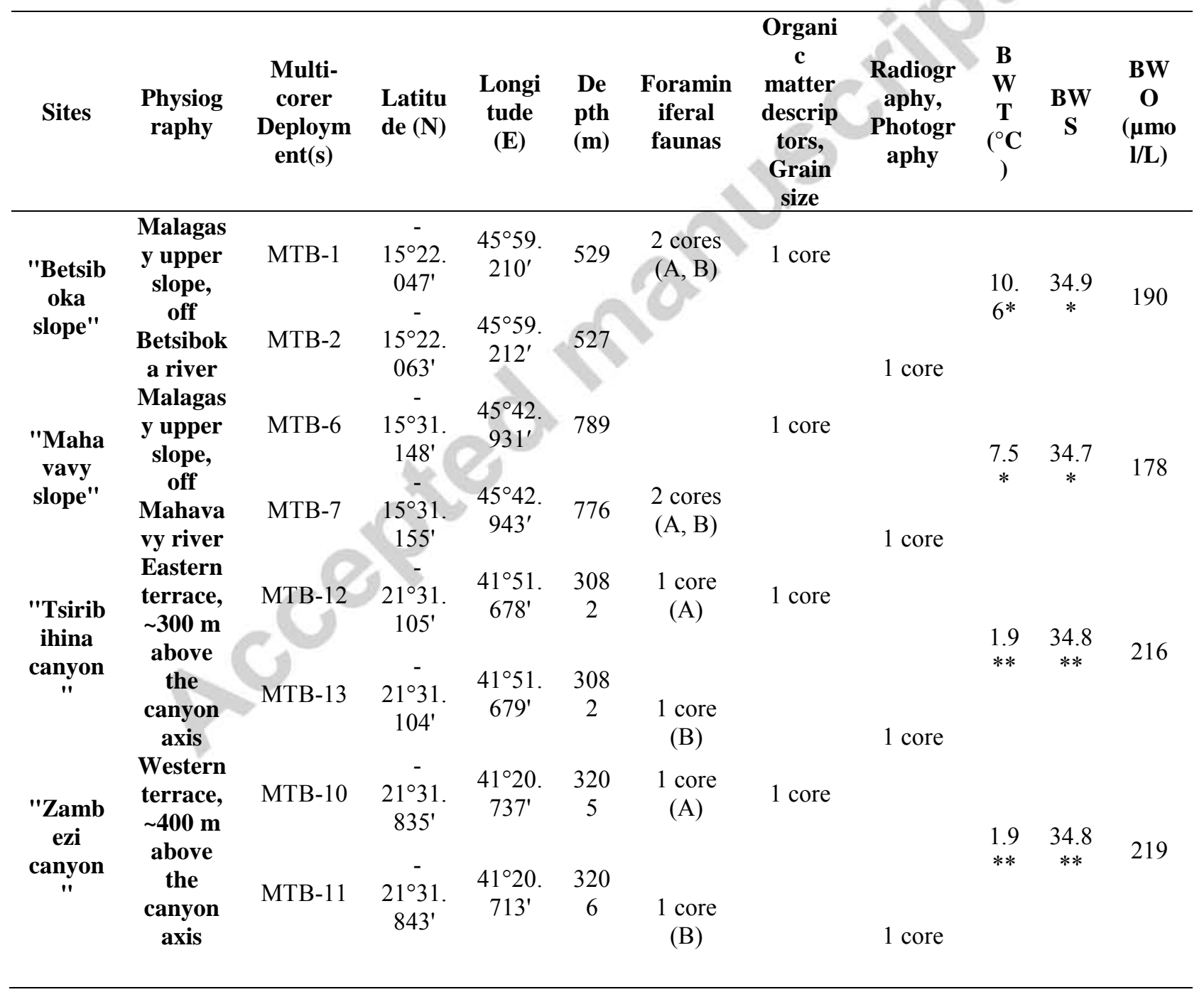


Table 2. Geochemical and sedimentological features of the four investigated stations. Abbreviations are explained in the Materials-and-Methods section. Only means values are presented. DW and FW mean respectively "Dry Weight" and "Fresh Weight".

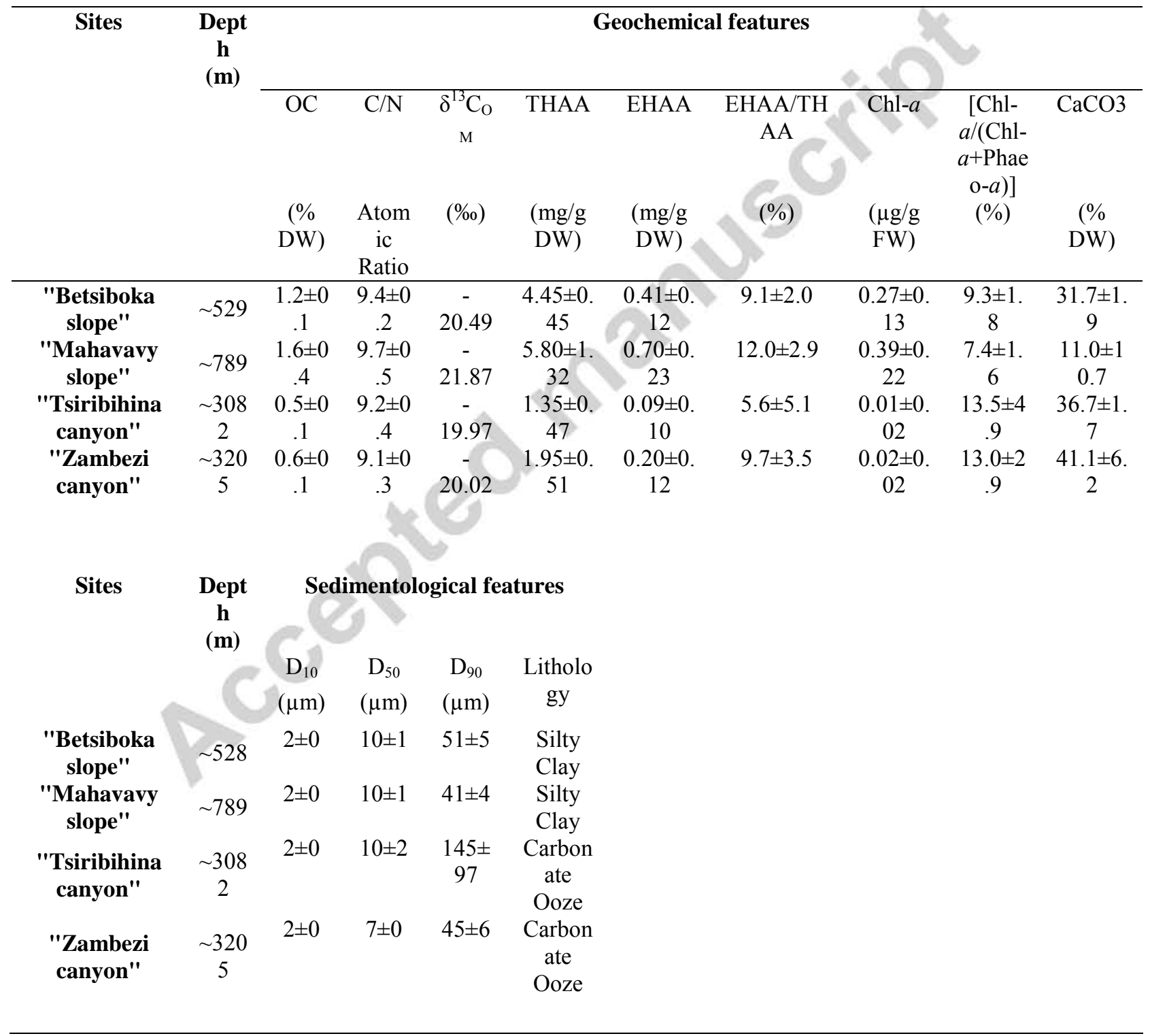


Table 3. Diversity indices (densities, $\mathrm{S}, \mathrm{H}$ ', $\mathrm{E}$, Berger-Parker, $\mathrm{E}\left(\mathrm{S}_{50}\right)$ ) calculated for the living (stained) foraminiferal faunas at the 4 stations ( 2 duplicate cores per station). On the third row, densities are normalized for a $100-\mathrm{cm}^{2}$-surface area. Ecological indices $\left[\mathrm{S}, \mathrm{H}, \mathrm{E}, \mathrm{E}\left(\mathrm{S}_{50}\right)\right]$ are explained in the Material-and-Methods section.

\begin{tabular}{|c|c|c|c|c|c|c|c|c|}
\hline \multirow[b]{2}{*}{ Duplicate cores } & \multicolumn{2}{|c|}{ "Betsiboka slope" } & \multicolumn{2}{|c|}{$\begin{array}{c}\text { "Mahavavy } \\
\text { slope" }\end{array}$} & \multicolumn{2}{|c|}{$\begin{array}{c}\text { "Tsiribihina } \\
\text { canyon" }\end{array}$} & \multicolumn{2}{|c|}{ "Zambezi canyon' } \\
\hline & $\begin{array}{c}\text { MTB- } \\
\text { 1A }\end{array}$ & $\begin{array}{c}\text { MTB- } \\
\text { 1B }\end{array}$ & $\begin{array}{c}\text { MTB- } \\
\text { 7A }\end{array}$ & $\begin{array}{c}\text { MTB- } \\
\text { 7B }\end{array}$ & $\begin{array}{c}\text { MTB- } \\
\text { 12A }\end{array}$ & $\begin{array}{c}\text { MTB- } \\
\text { 13B }\end{array}$ & $\begin{array}{c}\text { MTB- } \\
\text { 10A }\end{array}$ & $\begin{array}{c}\text { MTB- } \\
\text { 11B }\end{array}$ \\
\hline Species Richness S & 124 & 123 & 83 & 114 & 26 & 58 & 45 & 48 \\
\hline $\begin{array}{l}\text { No inarvuauais per } \\
\text { core } \\
\text { No }\end{array}$ & 866 & 812 & 1207 & 2704 & 294 & 204 & 297 & 194 \\
\hline Individuals $/ 100 \mathrm{~cm}^{2}$ & 1198 & 1123 & 1669 & 3740 & 407 & 282 & 411 & 268 \\
\hline Shannon Index H' & 4.1 & 4.0 & 3.0 & 3.2 & 1.9 & 3.4 & 2.1 & 3.0 \\
\hline Evenness Index E & 0.48 & 0.42 & 0.25 & 0.22 & 0.19 & 0.50 & 0.18 & 0.43 \\
\hline $\begin{array}{c}\text { Berger-Parker Index } \\
\text { Rarefaction Index }\end{array}$ & 0.09 & 0.13 & 0.21 & 0.19 & 0.58 & 0.16 & 0.58 & 0.29 \\
\hline $\mathbf{E}\left(\mathbf{S}_{50}\right)$ & 31 & 30 & 20 & 21 & 14 & 25 & 16 & 23 \\
\hline
\end{tabular}

\section{Highlights}

- Living foraminifera from the Mozambique Channel are studied for the first time.

- A multidisciplinary approach allows gathering reliable environmental information.

- Sedimentary organic matter plays a major role on diversity, density and microhabitat. 
Figure 1

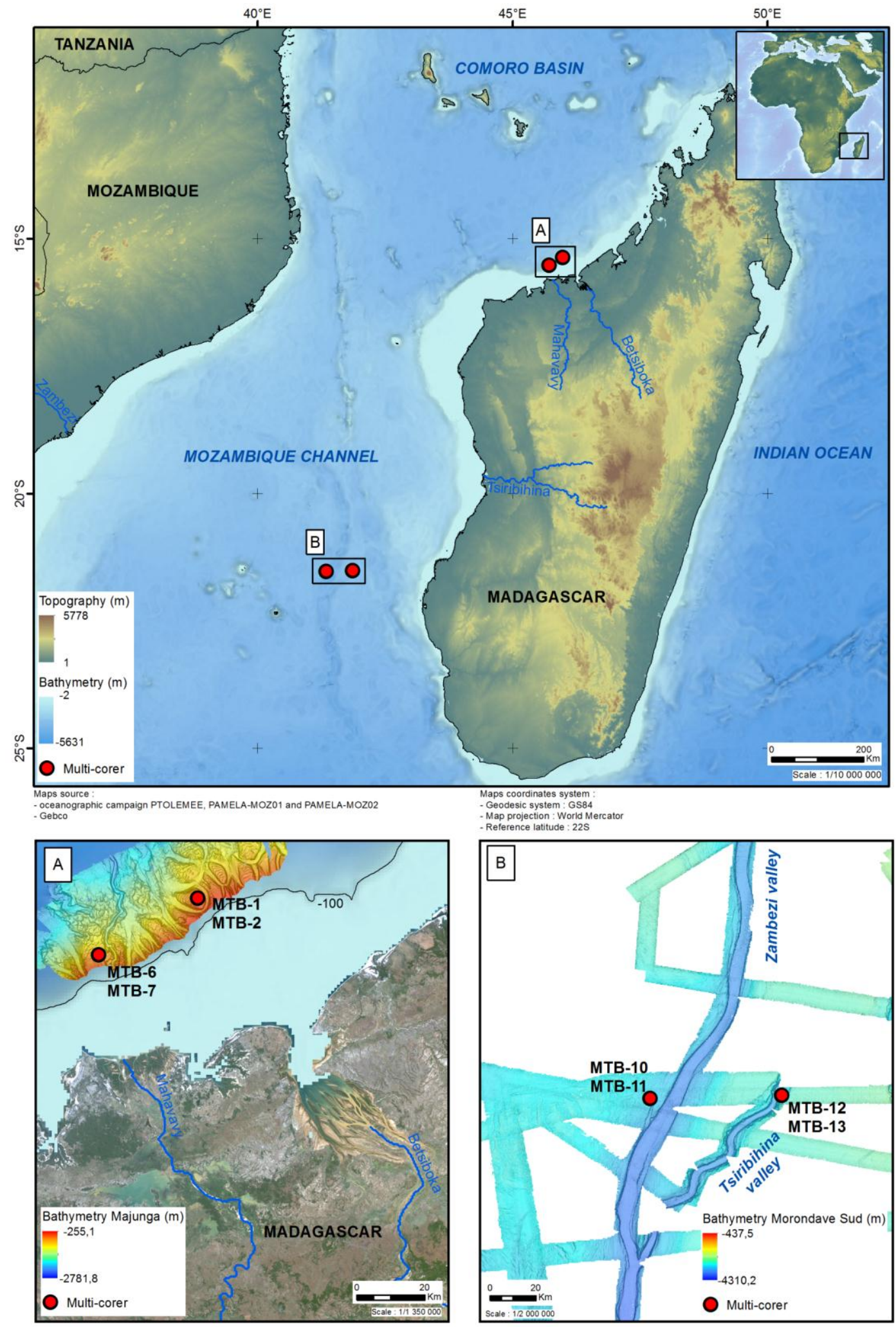


Figure 2

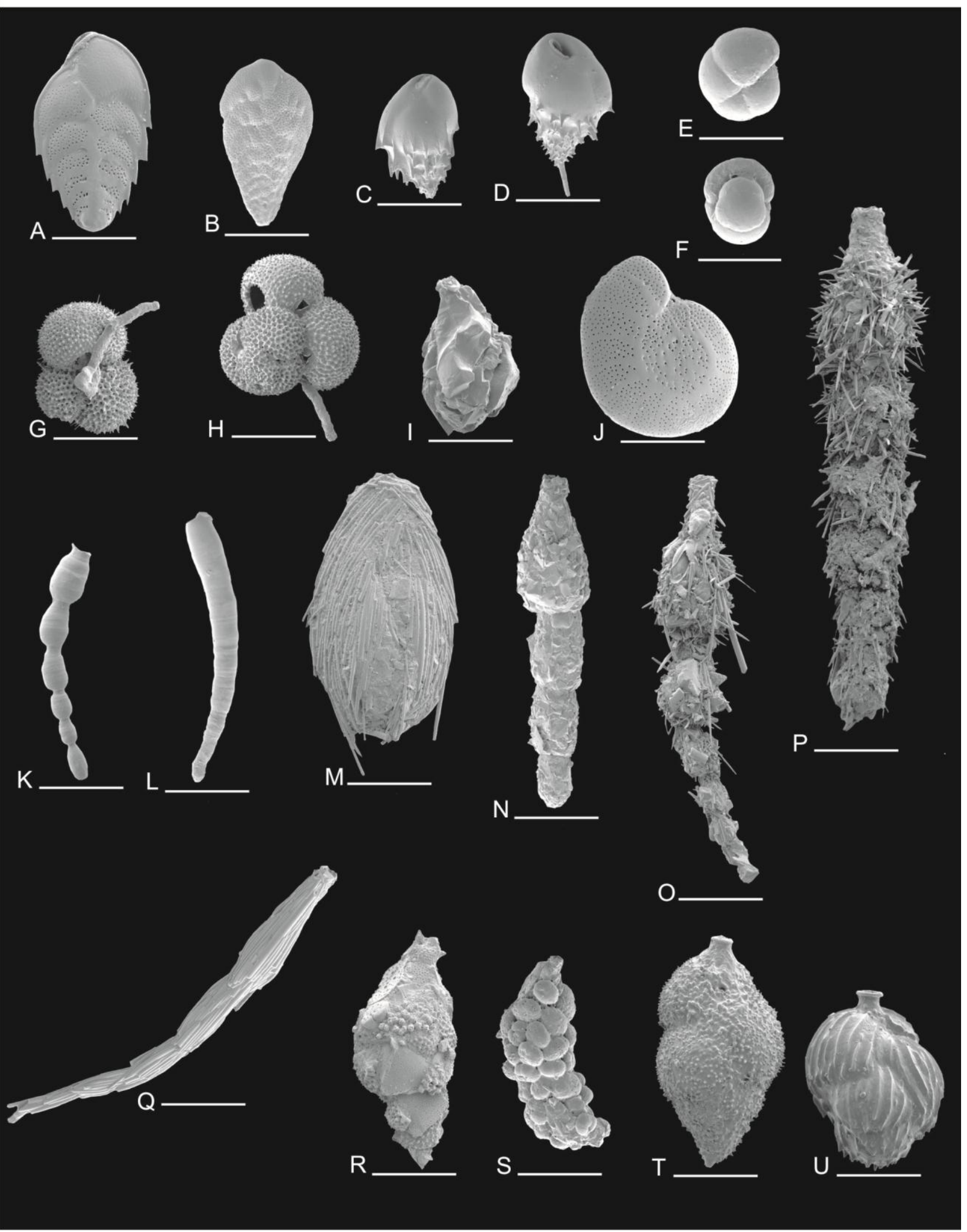


Figure 3

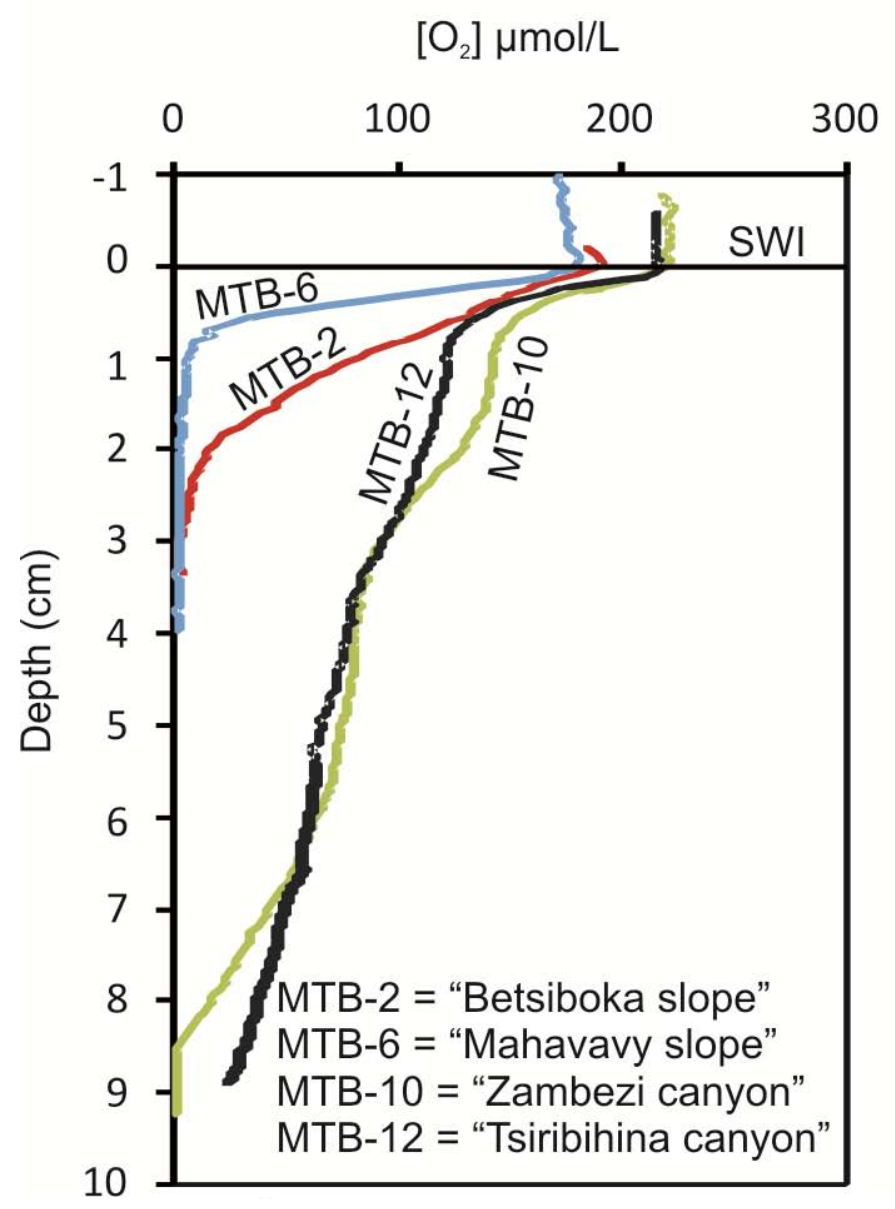


Figure 4

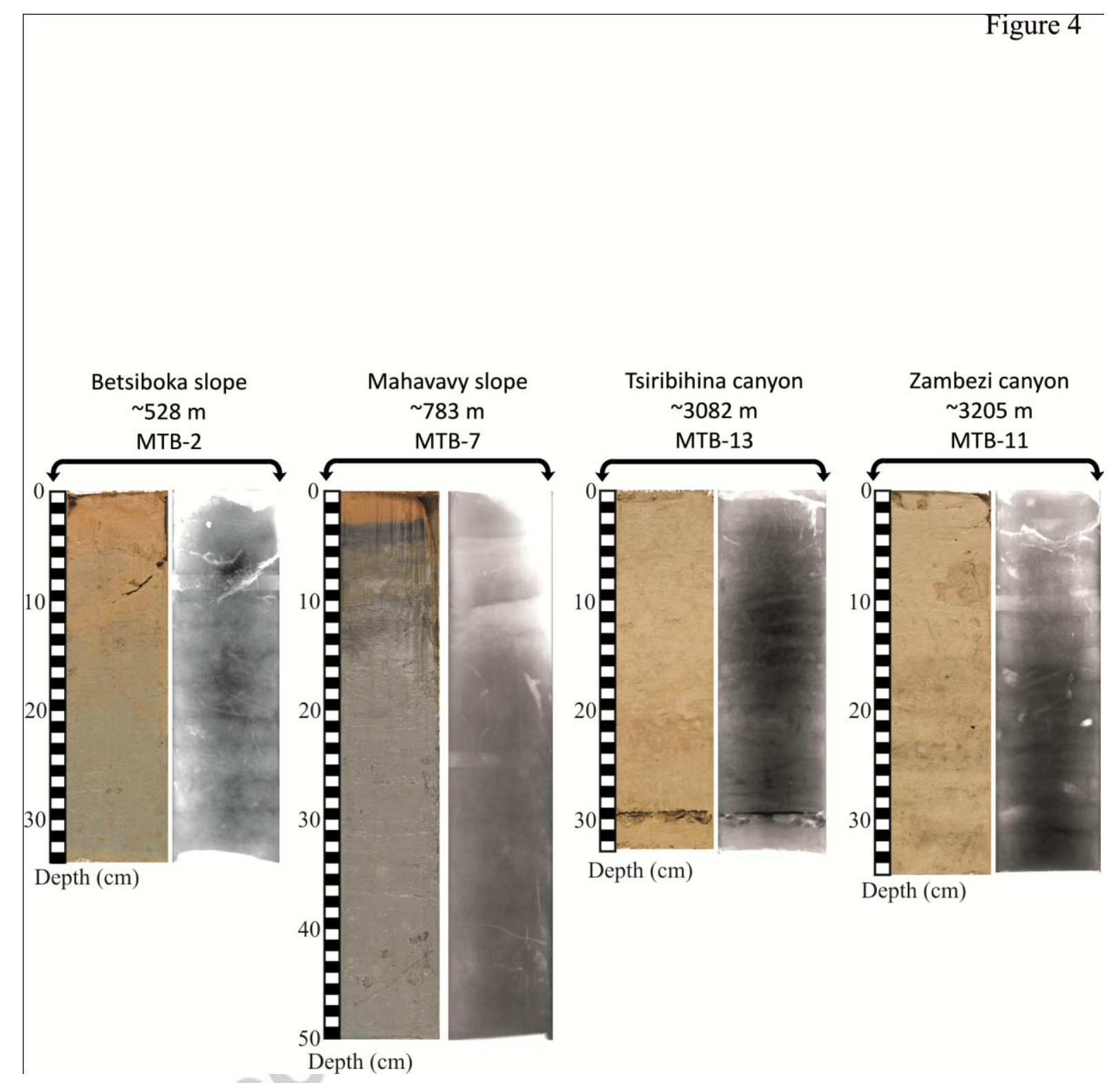


Figure 5

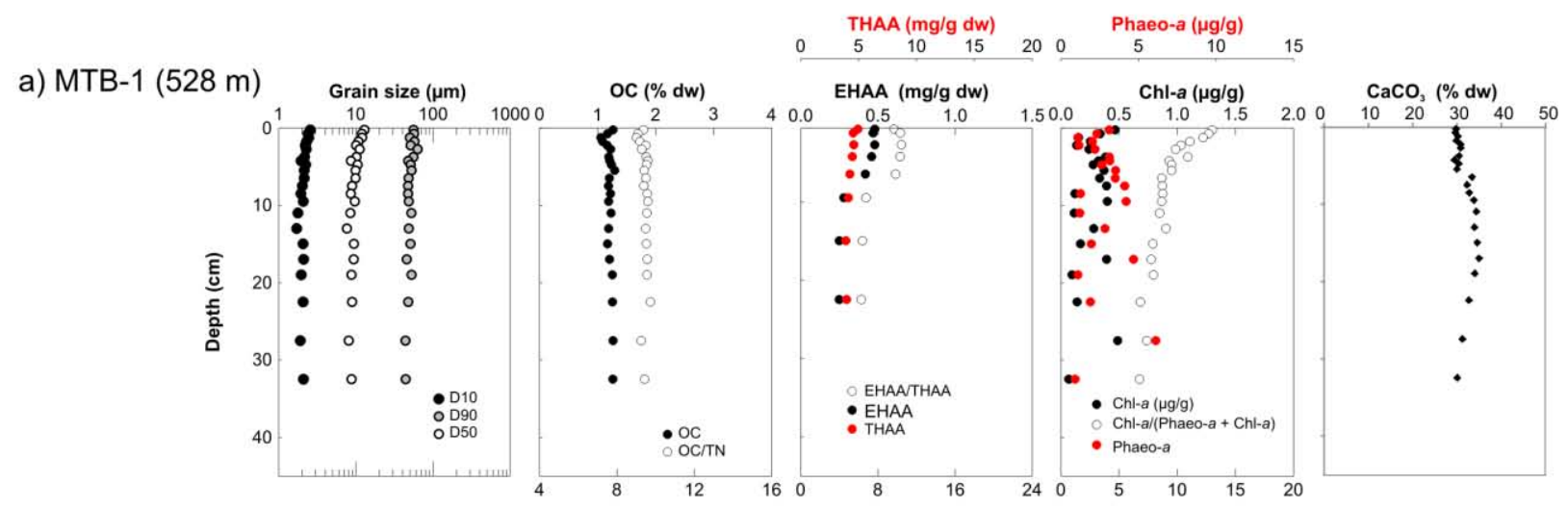

b) MTB-6 $(787 \mathrm{~m})$

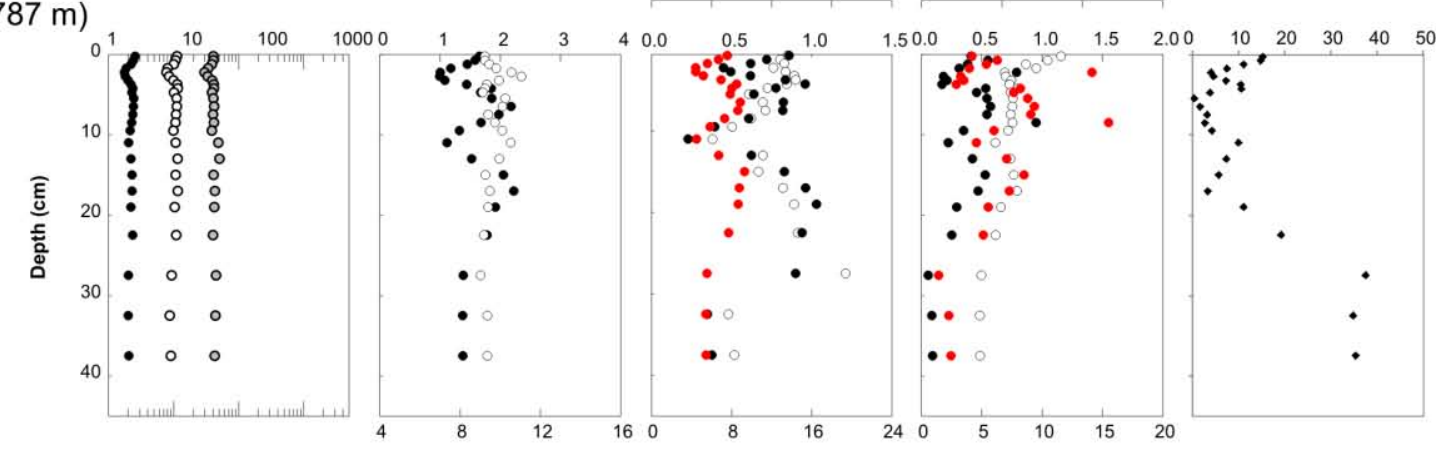

c) MTB-12 (3089 m)

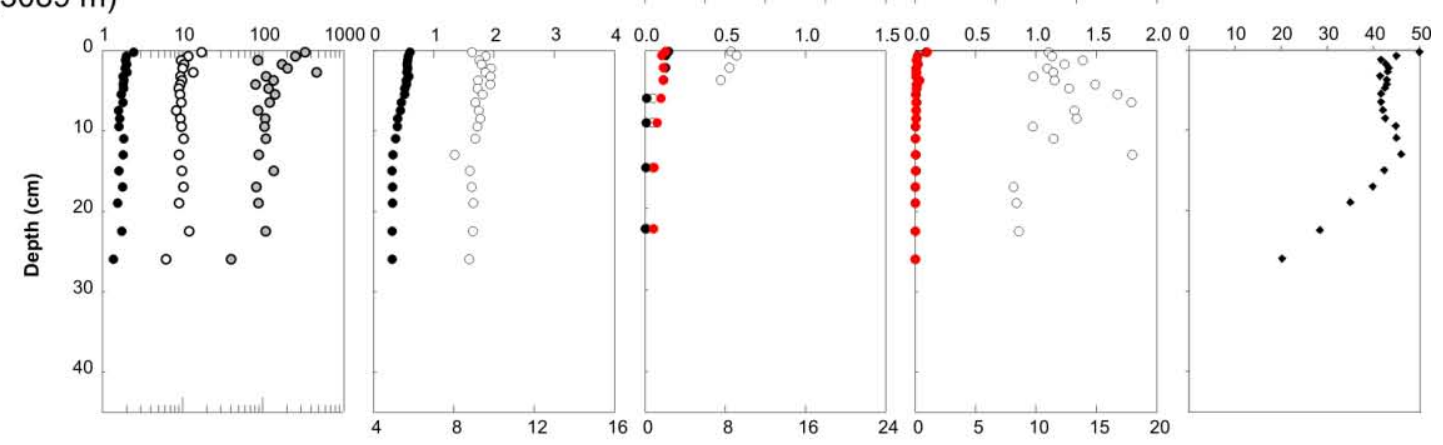

d) MTB-10 (3206 m)

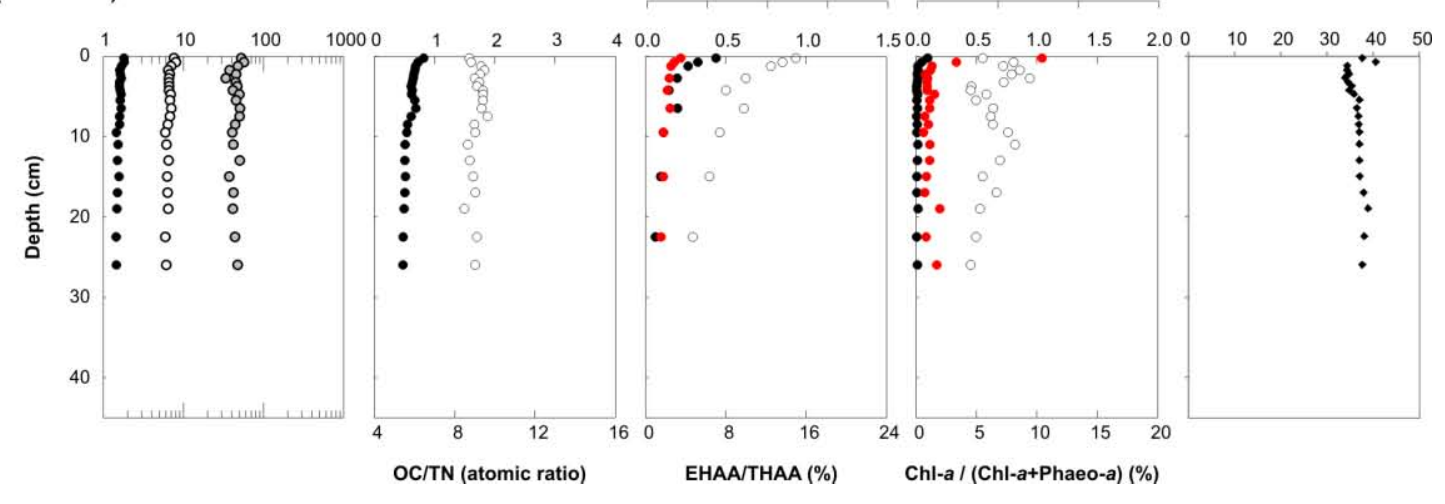


Figure 6

(a) Betsiboka slope Mahavavy slope Tsiribihina canyon Zambezi canyon

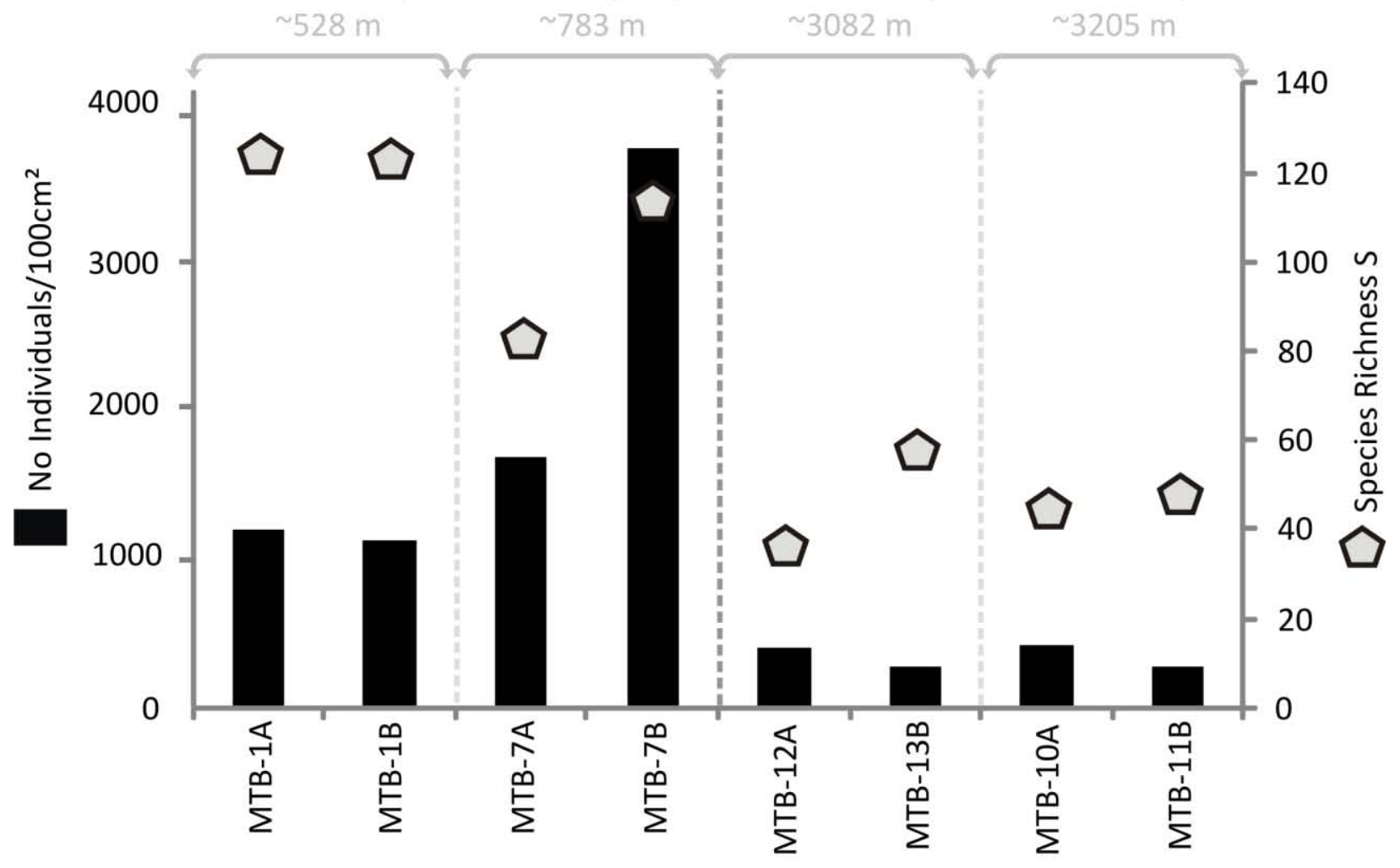

(b) Betsiboka slope Mahavavy slope Tsiribihina canyon Zambezi canyon

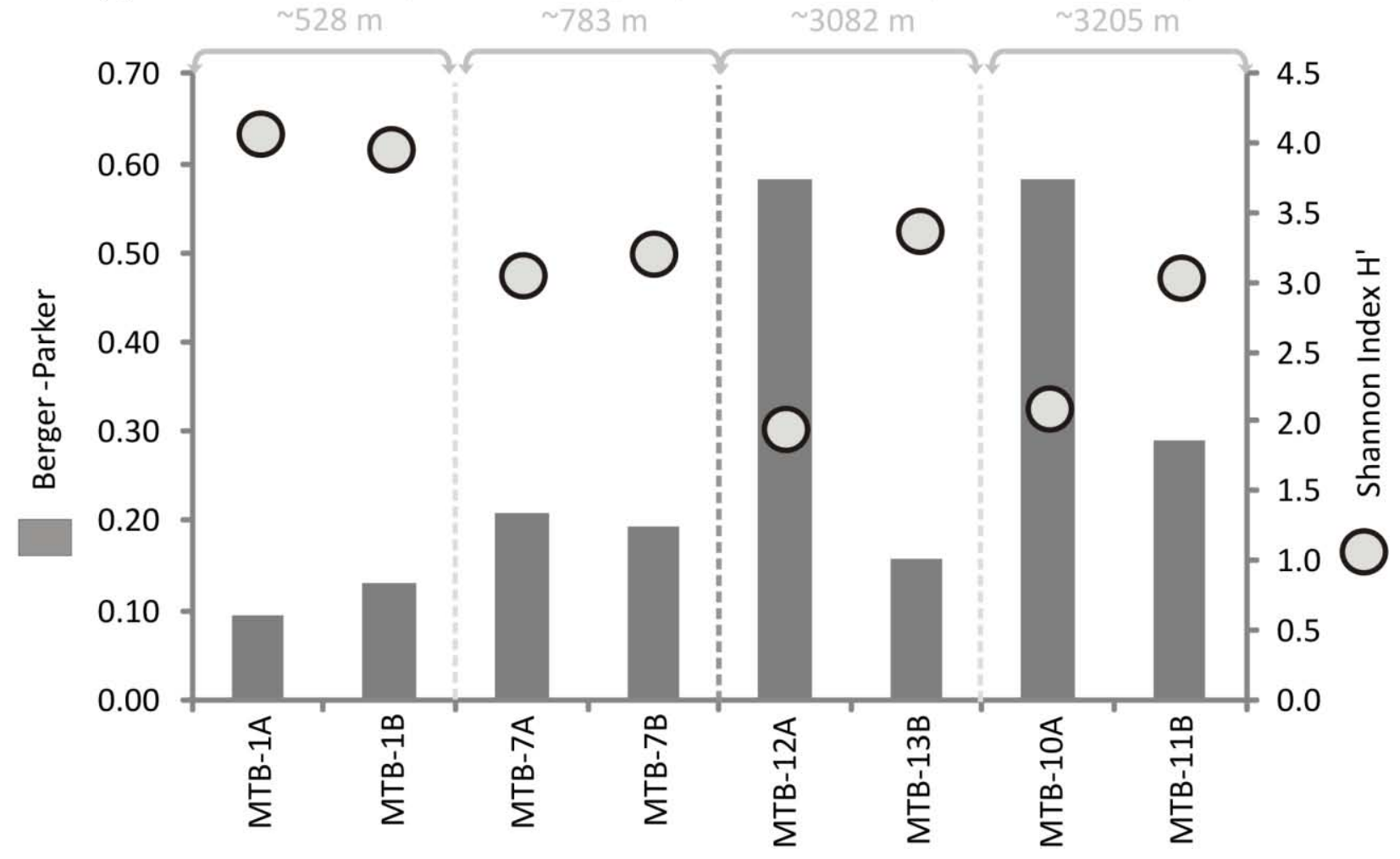



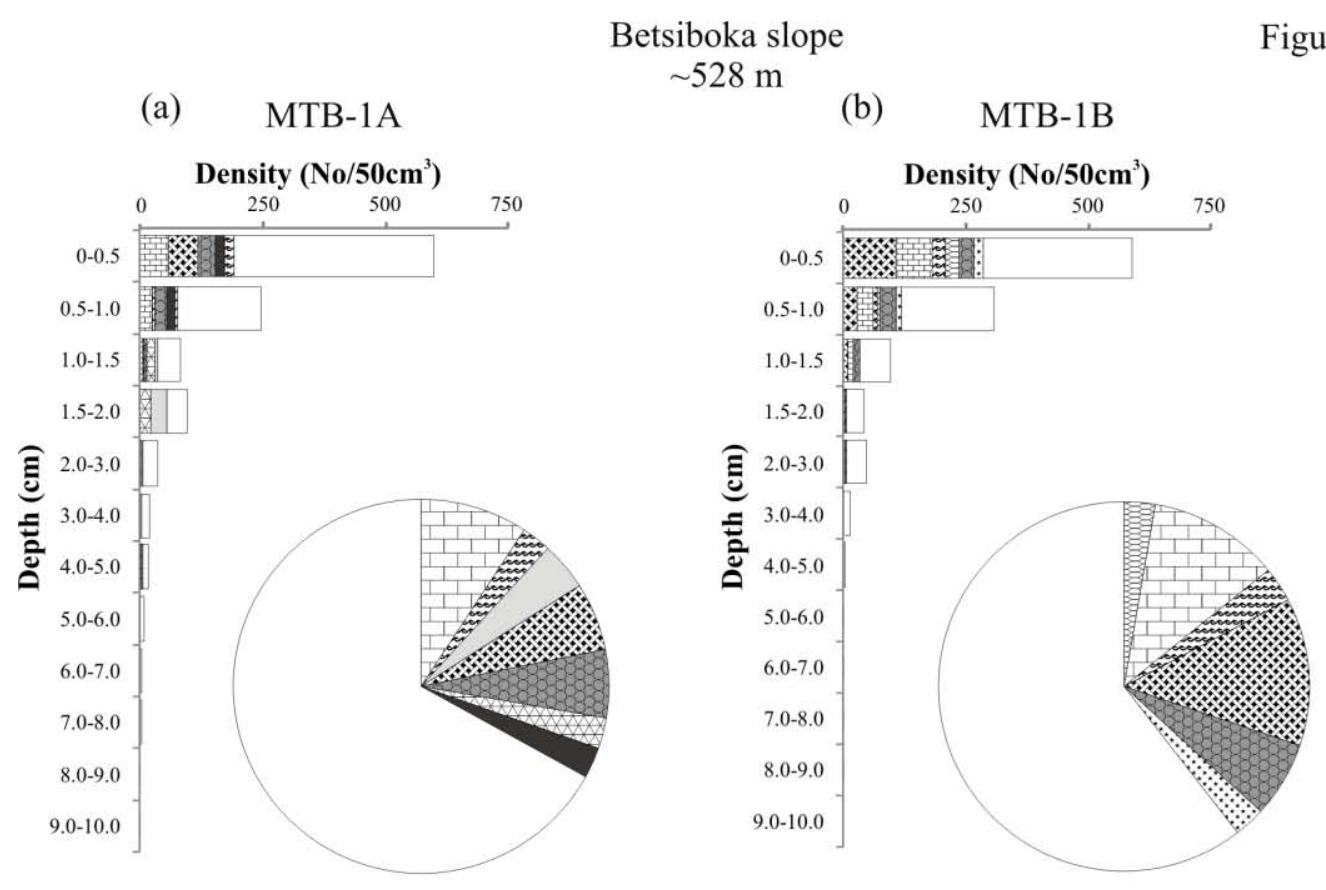

Figure 7 (A)

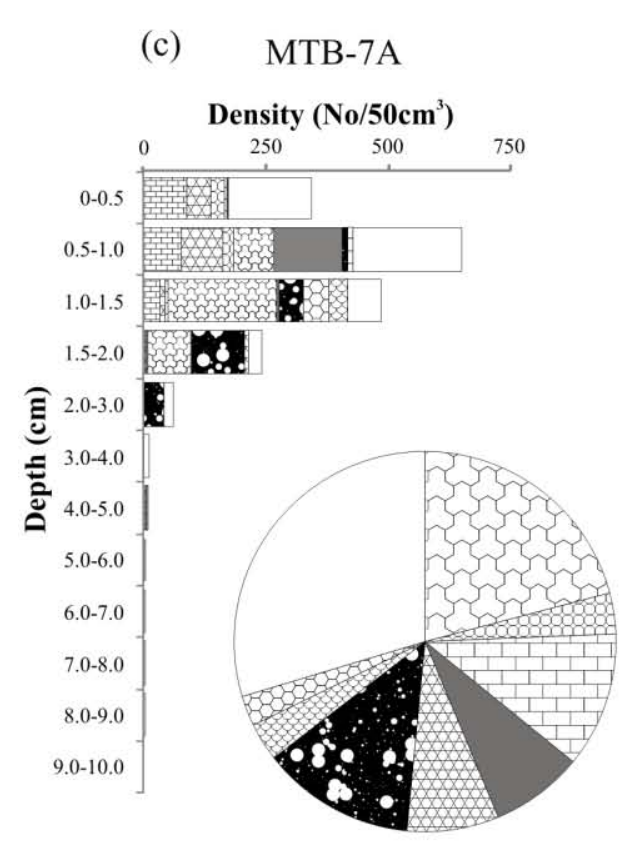

Mahavavy slope

$\sim 783 \mathrm{~m}$

(d) MTB-7B

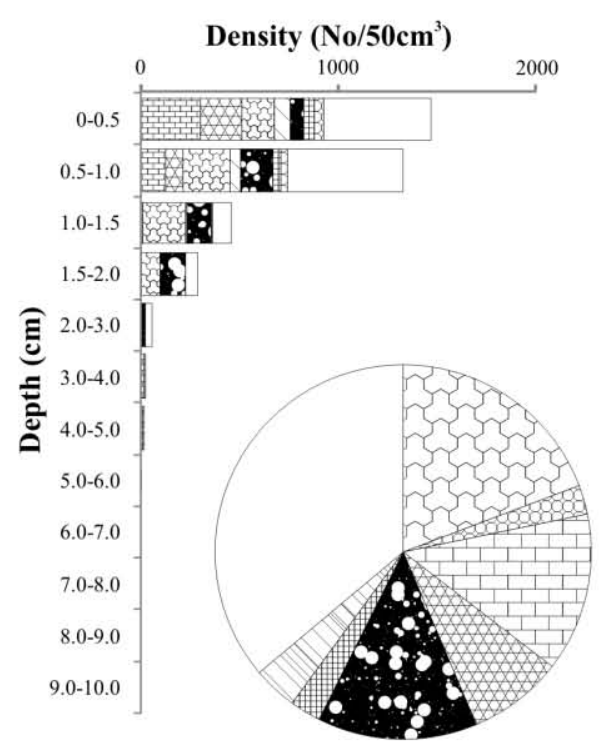

Bulimina marginata

Uvigerina hispida

Uvigerina semiornata

Reophax monile

Rotorbinella lepida

Lagenammina difflugiformis

The rest
Melonis barleeanus

Bolivina spathulata type 1

Lagenammina arenulata

Haplophragmoides bradyi

Bolivina alata

Bolivina spathulata type 2
2. Nouria compressa Bulimina inflata

Reophax hispidulus Reophax horrida Reophax spiculifera Nouria polymorphinoides 
Tsiribihina canyon

$\sim 3082 \mathrm{~m}$

(e) MTB-12A

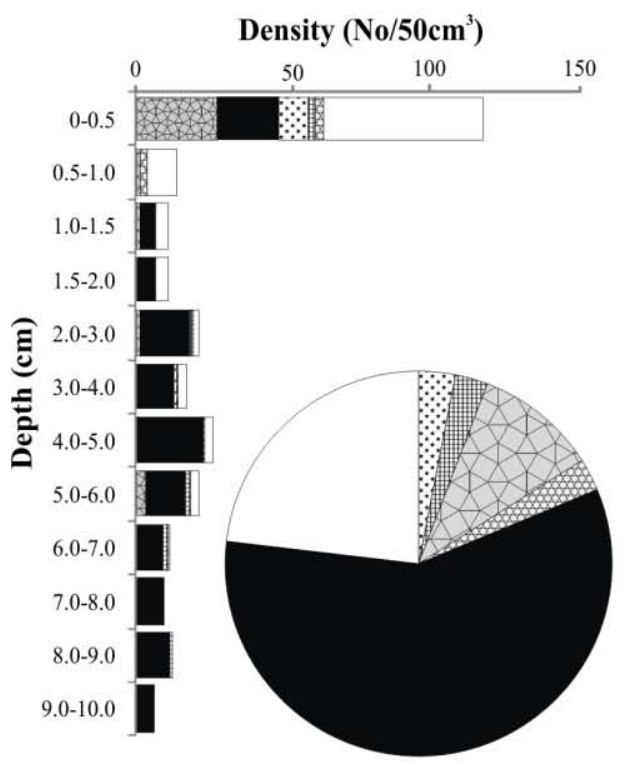

Figure 7 (B)

(f) MTB-13B

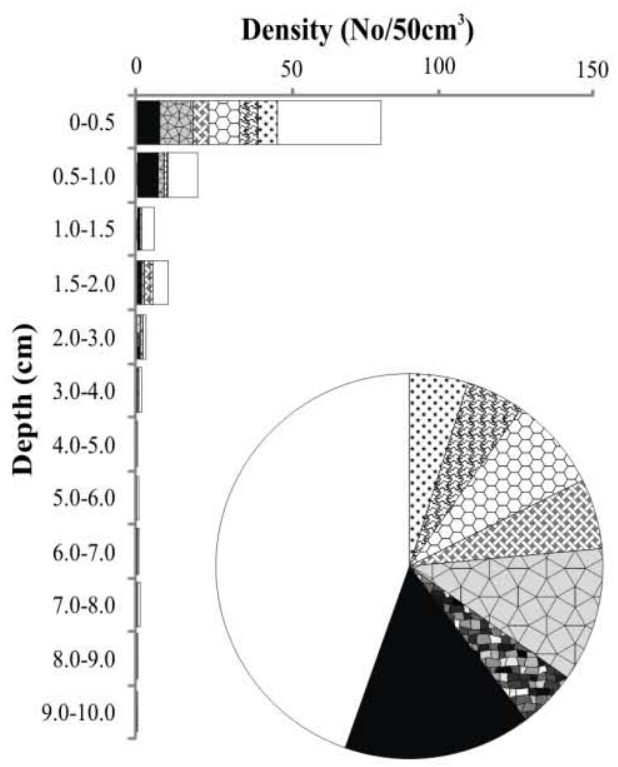

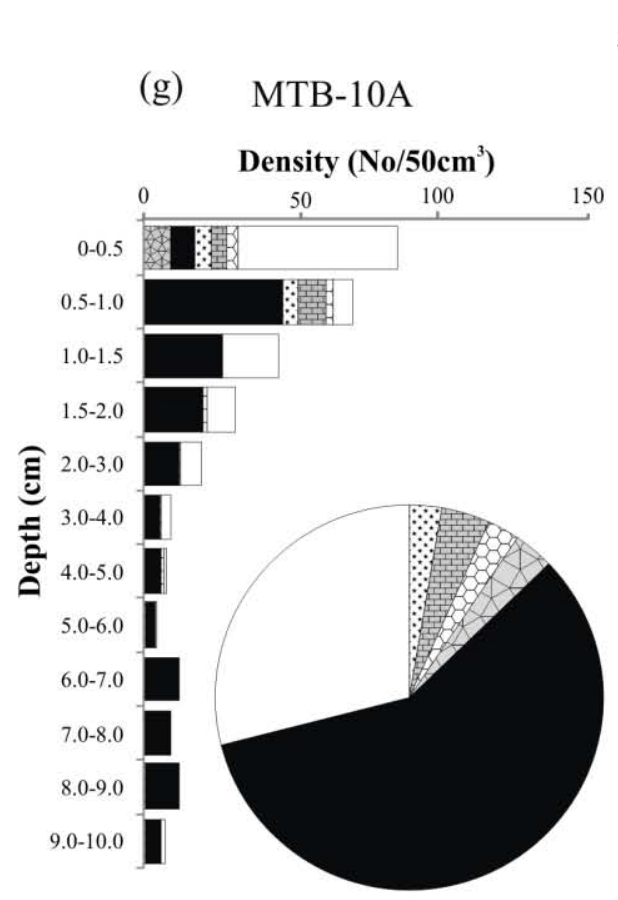

Zambezi canyon
$\sim 3205 \mathrm{~m}$
(h)
MTB-11B

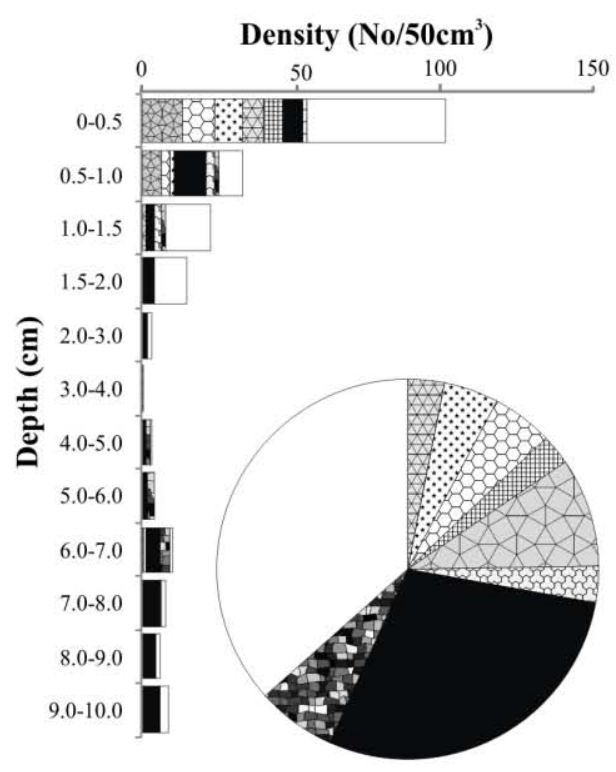

Reophax subfusiformis type 2 Lagenammina arenulata Reophax agglutinatus var: glomeratus

Reophax hispidulus

The rest
$R$

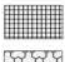

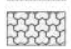
W
Ammoscalaria tenuimarg Reophax subfusiformis type 1 Saccorhiza ramosa Nodellum membranaceum type 1
Fis Nodellum membranaceum type 2 Reophax scorpiurus

琵琵望 Reophax dentaliniformis

Hospitella fulva 